\title{
ULUSLARARASI DOĞAL GAZ ALIM VE SATIM SÖZLEŞMELERINIIN DEĞISSEN ŞARTLARA GÖRE UYARLANMASI VE UYGULANACAK HUKUK
}

\author{
Adaptation of the Natural Gas Sale and Purchase Contracts to \\ Changing Circumstances and Applicable Law
}

Sema TAŞVEREN ${ }^{*}$

\begin{abstract}
ÖZET
Klasik uluslararası doğal gaz alım ve satım sözleşmeleri genellikle uzun dönemli sözleşmelerdir. Bu sözleşmeler uzun dönemli olmaları nedeni ile stratejik, ekonomik ve politik gelişmelerden etkilenmektedir. Sözleşmeler hazırlanırken taraflarca risk ve fayda analizi yapılmakta ve riskler paylaşılmaktadır. Alıcı sözleşmelerde yer alan "al ya da öde" hükmü ile miktar riskine, satıcı ise fiyat formülü ile fiyat riskine katlanmaktadır. Sözleşmeler imzalandıktan sonra tarafların kontrolü dışında gerçekleşen, öngörülemeyen ve beklenmeyen olaylar nedeni ile sözleşmelerin ekonomik dengesinin bozulması halinde ekonomik dengenin yeniden sağlanması ve sözleşmelerin başlangıçtaki pazarlığa ve risk paylaşımına yeniden kavuşturulması için yeniden müzakere edilerek değişen koşullara göre uyarlanması gündeme gelmektedir. Uyarlama sözleşmede fiyat revizyonu veya genel bir revizyon hükmünün bulunması halinde bu hükümler kapsamında gerçekleştirilmektedir. Bu hükümlerin yokluğunda sözleşmelerde mücbir sebep ve aşırı ifa güçlüğüne ilişkin düzenlemeler kapsamında uyarlama gerçekleştirilebilir. Sözleşmede bu tür hükümler yer alsa da almasa da sonuçta, uyarlamanın esas itibariyle sözleşmenin esasına uygulanacak hukukun izin verdiği ölçüde ve koşullarda yapılacağını söylemek yanlış olmaz. Taraflar arasında tahkim anlaşmasının varlığı halinde, hakemlerin, sözleşmenin değişen koşullara uyarlaması konusunda uyarlama yapma yetkisi sadece lex causaenın hakimiyeti altında olmayacaktır. Tahkim anlaşmasında tarafların uyarlama ile ilgili hususlara yer vermiş olmaları halinde hakem
\end{abstract}

Makalenin Geliş Tarihi: 30.06.2020, Makalenin Kabul Tarihi: 04.09.2020.

Dr., e-posta: sema.tasveren@gmail.com, ORCID: 0000-0001-8094-6004. 
heyeti bu hususu göz ardı edemez. Nihayet, tahkim usulüne uygulanacak hukukun hakemlerin bu konudaki yetkisi ile ilgili hükümleri de hakemlerin uyarlama yapma yetkisi üzerinde etkili olacaktır.

Anahtar Kelimeler: Doğal Gaz Alım ve Satım Sözleşmeleri, Değişen Şartlar, Uyarlama, Uygulanacak Hukuk, Tahkim.

\begin{abstract}
Traditional international natural gas sale and purchase contracts have pattern of long term contracts. Therefore, these contracts are affected by strategic, economic and political developments. During the preparation of the contracts risk and rewards analysis are made by the parties and risks are shared. Buyers assume volume risk through take or pay provisions whereas sellers assume price risk through price provisions. However, after the conclusion of the contracts if the original equilibrium of agreement has been changed because of the unexpected, unforseen events beyond the control of the parties, the question of renegotiation and adjustment of the contract to restore the original bargain and the allocation of risks initially agreed arises. If there is a price revision or renegotiation provision in the agreement, the adaptation is made within the scope of these provisions. In the absence of these provisions, force majeure and hardship provisions may be applied. However, adaptation would be subject to the requirements provided by applicable law to the contract, irrespective of the existence of such provisions in the contract. However, lex causa would not be the sole law which governs the power of arbitral tribunal for the disputes arising out the adaptation/adjustment of the contract when there is an arbitration agreement between parties. Indeed, any arbitral tribunal would respect parties' intention regarding adaptation of the contract in arbitration agreement. The provisions of lex arbitri with regard to arbitral tribunal's power of adaptation and adjustment should also be taken in to consideration.
\end{abstract}

Keywords: Natural Gas Sale and Purchase Contracts, Changed Circumstances, Adaptation, Applicable Law, Arbitration.

\title{
GİRIŞ
}

Uluslararası petrol ve doğal gaz projeleri stratejik, politik ve ekonomik unsurlardan etkilenen ve aynı zamanda bu etkileri yaratan projelerdir. $\mathrm{Bu}$ projeler petrol ve doğal gaz çıkarma ve enerji üretim tesisleri, açık deniz platformları, rafineriler, boru hattı ve iletim ağı, gemi ile taşımada kullanılan 
terminalleri içeren çok kapsamlı ve maliyetli projeler olup yapımı uzun yıllar almaktadır. Dolayısıyla bu projeler teknik ve yasal boyutta ciddî bir planlamayı ve finansman açısından ciddî risk ve fayda analizini gerekli kılmaktadır. Hatta projenin birden çok ülkeyi ilgilendirmesi halinde hükûmetler arası iş birliğini, özellikle ülkelerin her birinin çevre ve arazi kullanımı da dâhil yasal ve idarî düzenlemelerine uymayı gerektirmektedir. Sonuçta petrol ve doğal gaz projeleri, keşif, ticaret, finansman, teknik, yönetim ve çevre ile ilgili risklerin ve doğal afetlerin yanı sıra politik risklerin yoğun olarak tehdidi altındadır ${ }^{1}$. Enerji projelerine ilişkin yatırım sözleşmelerinde, özellikle ev sahibi devletteki politik gelişmelerin, projenin ekonomik temellerini çökertme ihtimali bulunmaktadır. Politik riskin en yaygın türü, ev sahibi devletin yabancı yatırımlara kamulaştırma (expropration) veya millîleştirilme (nationalization) gibi yollarla el atmasıdır (taking). Daha az rastlansa da potansiyel olarak eşit derecede yıkıcı politik risk örnekleri de bulunmaktadır. Bunlar üretim, geliştirme ve hizmet sözleşmelerinin yeniden pazarlık konusu edilmesidir. Politik riskin başka isimler altında ortaya çıktı̆̆ 1 durumlar ise genellikle sermaye ve döviz gelirinin transferi ile ilgilidir². Görüldüğü üzere, bu projelere dayanan sözleşmelerin en dikkat çeken özelliği, ekonomik, politik ve stratejik etkilere açık olması ve bu tür etkileri doğurmasının yanı sıra, uzun dönemli olmaları, yüksek sermaye gerektirmesi ve devletlerin bu sözleşmelere müdahalesidir.

Uzun süreli uluslararası ticarî sözleşmeler bakımından tarafların öngörmediği ve dolayısıyla doğrudan sözleşmelerinde yer vermediği olaylar ortaya çıkabilir. Bu durum tarafların birbirlerinin siyasî ve hukukî sistemini tanımamasından veya başka nedenlerden kaynaklanabilir. Genel olarak uluslararası ticarî işlemlerin ve özel olarak uluslararası ticarî sözleşmelerin ilgili ülkelerdeki iş ve ticaret hayatına ilişkin kuralları ile sıkı bir ilişkisi bulunmaktadır. Pek çok riskin istikrarlı ekonomik ve politik bir yapı ile istikrarlı bir hukuk düzeninin bulunmamasından kaynaklandığı görülmektedir.

Uzun dönemli olan doğal gaz yatırımlarında ve sözleşmelerinde, yukarıda belirtilen hususların da etkisiyle, taraflar bazı sorunları sözleşme ilişkisinin başında öngöremeyebilir. Bazen, söz konusu sözleşmelerin gelecekteki olaylardan etkilenmeleri kaçınılmaz bir durum olarak karşımıza

1 BLYSCHAK, P. M.: “Arbitrating Overseas Oil and Gas Disputes: Breaches of Contract Versus Breaches of Treaty”, Journal of International Arbitration 2010, Vol. 27, No, 6, s. 585.

2 BLYSCHAK, s. 586. 
çıkar. Tarafların varsayımlarında önemli bir değişiklik meydana geldiğinde ve bu durum tarafların başlangıçtaki kâr ve sermayenin geri dönüşü konusundaki beklentilerini önemli ölçüde etkilediğinde sözleşmenin ekonomik dengesi bozulmuş demektir. Gerçekten de sözleşmenin içinde bulunduğu hukukî, ekonomik ve politik çevrenin istikrarsızlı̆̆ 1 , iş birliğinin sürdürülmesini sıkıntıya sokmakta, sözleşme süresinin uzun olması da sözleşmede belirsizlik ve spekülasyonları artırarak sözleşmenin değişen şartlara uyarlanması ihtiyacını ortaya çıkarmaktadır ${ }^{3}$. Böyle bir durumda yeniden müzakere, sözleşmenin uyarlanması için esneklik sağlamak suretiyle sözleşmenin ekonomik dengesini tekrar kurmaktadır ${ }^{4}$. Hatta bazen bu durum tarafların pozisyonlarının dondurulmasına benzetilmektedir ${ }^{5}$.

Uzun dönemli sözleşmelerde geçmişte yaygın bir şekilde kullanılan istikrar kayıtları ile yeniden müzakereye ilişkin sözleşme hükümlerinin aynı amacı taşıdı̆̆ kurmaya imkân vereceği düşünülebilir. Özellikle yatırım sözleşmelerinde esnek ve değiştirilebilir hükümlerin ev sahibi devletin lehine olduğu ve yeniden müzakere hükümleri ile ev sahibi devletin temel yatırım şartlarında kendi lehine değişiklik yapabileceği belirtilmektedir. İstikrar kayıtları, sabitlenmiş bir hukukî statüyü hedeflemekte ve sözleşmenin karşı tarafını güvence altına almaktadır. Dolayısıyla bu iki hüküm arasındaki yarışma devam etmektedir. İstikrar kayıtlarının faydasının kesin olmaması nedeniyle yeniden müzakere hükümleri yatırım sözleşmelerinde devletin tek taraflı değişiklik ve çekilmelerine karşı yatırımcıya bir koruma sağlamaktadır.

Kısaca ifade etmek gerekirse, yeniden müzakere hükümleri sözleşme ilişkisini dondurmadan değişen şartlara göre esnek ve gözden geçirilebilir bir hale getirmeyi amaçlamaktadır. Yeniden müzakere hükümleri devletin

3 BÖCKSTIEGEL, K-H.: “Hardship, Force Majeure and Special Risk Clauses”, Adaptation and Renegotiation of Contracts in International Trade and Finace, (Ed. Robert HORN), Kluwer Law International, Deventer/Netherlands/Antwerp/Boston/London/Frankfurt, 1995, s. 160-161.

4 Sözleşmelerin uyarlanması, sözleşmenin bozulan ekonomisini tekrar sağlama amacı gütmektedir. Sözleşmenin kurulmasından sonra gerçekleşen beklenmedik olaylar nedeniyle borcun ifasının dürüstlük kuralı gereği kendisinden beklenemeyen borçlu, sözleşmenin uyarlanması yolu ile hakkaniyete uygun bir çözüme kavuşmaktadır. Nitekim hukuku katı uygulamak en büyük adaletsizliği doğurabilmekte ve sözleşmenin uyarlanması ile sözleşme adaleti yeniden sağlanmaktadır. BAYSAL, B.: Sözleşmenin Uyarlanması, On İki Levha, İstanbul 2009, s. 16; EREN, F.: Borçlar Hukuku Genel Hükümler, Yetkin Yayınları, Ankara 2019, s. 541-542.

5 QURASHI, Z.: "Renegotiation of International Petroleum Agreements", Journal of International Arbitration 2005, Vol. 22, No. 4, s. 264-266. 
egemenlik hakkının ihlaline yol açmadan sözleşme değişikliğine de imkân vermektedir. İstikrar kayıtları, ev sahibi devletin yasama yetkisini kısıtlayarak yatırımcıya zarar verilmesini engelleme özelliğine sahip iken, yeniden müzakere hükümleri özel hukuka ilişkindir. Yeniden müzakere hükümleri yatırımcının yeni bir kanun ya da hukukî düzenleme nedeniyle zarara uğraması halinde bunun tazminini de mümkün kılmaktadır. Yeniden müzakere hükümleri, sözleşme değişikliğine ve gerektiğinde tazminata imkân verdiği için iki yönlü işleyen hükümler olarak kabul edilmektedir ${ }^{6}$

Uzun süreli doğal gaz ve petrol sözleşmelerinin yukarıda sözü edilen teknolojik, politik ve ekonomik değişikliklerin yanı sıra bazı hükümlere sözleşmede yer verilmemiş olmasından kaynaklanan çeşitli sorunların çözümü, sözleşme hukukunun iki temel ilkesi arasındaki dengeye bağlidır: Pacta sunt servanda ve clausula rebus sic stantibus ${ }^{7}$. Birincisi tarafların başlangıçtaki mutabakatına işaret ederken, ikincisi sözleşmenin başlangıçtaki ekonomik dengesini korumak amacıyla sözleşme süresi boyunca tarafların başlangıçtaki mutabakatına belirli bir esneklik sağlama fikrinden hareket etmektedir. O halde, özellikle uluslararası tahkim kaydı bulunan sözleşmelerde, hakemlerin sözleşmedeki boşlukları doldurması veya sözleşme hükümlerini revize etmesi yetkisinin sözleşmeye bağlılık ile ticarî esneklik arasındaki ikilemin çözülmesine bağlı olduğu söylenebilir ${ }^{8}$.

Petrol ve doğal gaz sözleşmeleri sıklıkla sözleşmelerin uyarlanması ve gözden geçirilmesinde tarafların belirli bir süre içinde anlaşamamaları halinde, uyuşmazlığın tahkim yolu ile çözümünü öngörmektedir. Uyarlama, genellikle petrol fiyatlarnda yaşanan değişiklikler, ambargo, enflasyon gibi genel karakterli olaylar nedeniyle olabileceği gibi belirli sözleşmelere ilişkin de olabilir. Bu durumda hakemlerin ve mahkemelerin sözleşmeleri değişen şartlara göre uyarlamaları beklenmeyen olağanüstü olayların ortaya çıkmasına bağlıdır. Önemli olan sözleşme yapılmasından sonra ortaya çıkan ciddî değişikliklerdir ${ }^{9}$. Bazı sözleşmelerde tarafların anlaşamaması halinde uyuşmazlığın tahkime götürüleceği yer almakta, ancak hakemlere sözleşmeyi revize etmeye ilişkin açık bir yetki verilmemektedir. Buna karşılık, bazı sözleşmelerde hakemlerin sözleşmenin revizyonu ile birlikte durumla baş

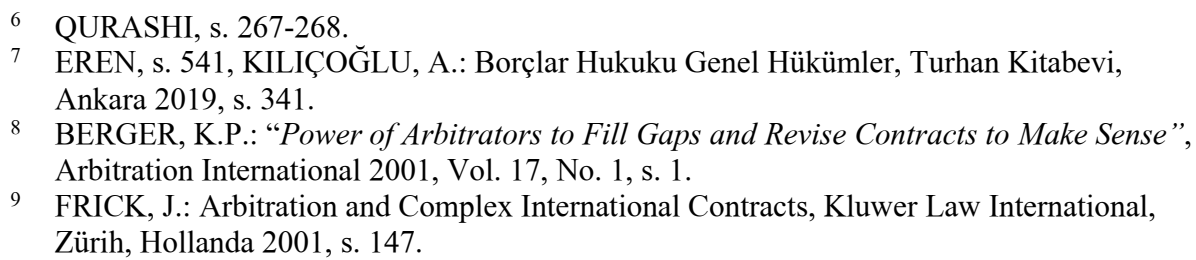


etme yöntemlerine ilişkin hükümler yer almaktadır. Bütün bunlara ilaveten bazı devletlerin uluslararası tahkime ilişkin süre, kapsam veya onay alma gibi sinırlandırmaları da dikkate alınmalıdır ${ }^{10}$.

Sözleşmede yeniden müzakere etme yükümlülüğü (obligation to renegotiation) ile ilgili özel bir hükme yer verilmiş olsa da olmasa da, ilgili tarafın (renegotiation), sözleşme değişikliği hakkı olup olmadığı ve bunun kapsamını sözleşmenin esasına uygulanacak hukuka tâbidir. Sözleşmede hüküm varsa, esasa uygulanacak hukukun konuya ilişkin emredici düzenlemelerine aykırı olmadıkça sözleşme hükmü çerçevesinde hareket edileceği açıktır. Sözleşmede hüküm olmadığı hallerde ise, hakemler veya mahkemeler tarafından doğrudan doğruya esasa uygulanacak hukukun öngördügü kurallar uygulanacak, o hukukun izin verdiği ölçüde sözleşme değişikliği talep etme hakkı (right to ask for contractual change) olarak adlandırılan mekanizma devreye girecektir. Bu durumda sözleşmenin sona erdirilmesi, mahkeme veya tahkim yolu ile uyuşmazlığın çözümü veya yeniden müzakere etme seçenekleri gündeme gelmektedir ${ }^{11}$.

10 Kenya üretim paylaşım sözleşmesinde Hükûmet ile yüklenicinin sözleşmede yer alan uygun değişiklik konusunda yüklenicinin hükûmete gönderdiği talep tarihinden itibaren 90 gün içerisinde anlaşamamaları halinde yüklenicinin uyuşmazlığı sözleşme kapsamında tahkime götürebileceği yer almaktadır. Buna karşılılık, Malta sözleşmesinde, hakemlere verilen yetki çok daha geniş kapsamlıdır. Hakemler önemli değişikliğe ilişkin şartların gerçekleşip gerçekleşmediğine ve gerçekleştiyse yüklenicinin ekonomik haklarının bu değişiklikten önceki duruma gelebilmesi için uyarlamanın gerekli olup olmadığına karar vermekle yetkilidir: MANIRUZZAMAN, A.F.M.: "International Energy Contracts and Crossborder Pipeline Projects: Stabilization, Renegotiation and Economic Balancing in Changed Circumstances- Some Recent Trends", Oil, Gas \& Energy Law Intelligence 2006, Vol. 4; No. 4 , s. 7.

İran Anayasası'nın 139. Maddesinde ise tahkime ilişkin Meclis onayını gerektiren bir hüküm bulunmaktadır: "Кamu ve devlet mülkiyeti ile ilgili taleplerin çözülmesi veya tahkime yönlendirilmesi her durumda Bakanlar Kurulunun onayına bağlldır ve Meclis bu konularda bilgilendirilmelidir. Anlaşmazlığın taraflarından birinin yabancı olduğu ve tamamen yerli olan önemli durumlarda Meclis'in onayı da alınmalıdır."

İran Devleti ile yapılan sözleşmelerden doğan uyuşmazlıkları tahkim yoluyla çözmek isteyen yatırımcılar bu nedenle İran Meclisi'nin onayını almalıdır.

Bkz. https://www.constituteproject.org/constitution/Iran_1989.pdf?lang=en (Edinim Tarihi: 04.09.2020)

11 PETER, W.: Arbitration and Renegotiation of International Investment Agreements, Second and Enlarged Edition, Kluwer Law International,The Hague/Boston/London 1995, s. 201. EREN, uyarlamanın sözleşmede ve kanundaki bir hükme göre yapılması ve hâkim kararına dayanmasına göre sözleşmeye dayalı uyarlama, kanunî uyarlama ve yargısal uyarlama ayrımı yapmaktadır: EREN, s. 543-545. 


\section{§ 1ULUSLARARASI DOĞAL GAZ ALIM VE SATIM SÖZLEŞMELERINIIN ${ }^{12}$ ÖZELLİK GÖSTEREN HÜKÜMLERİ}

Doğal gaz alım ve satım sözleşmeleri, sözleşmede belirli dönemler için belirlenen doğal gazın alım ve satımı ile tarafların üstlendikleri risklere ilişkin ayrıntı1ı hükümler içermektedir. Sözleşmelerde önem arz eden hükümler, alıcının doğal gazı teslim noktasında alım yükümlülüğü ve satıcının teslim noktasında gazı hazır bulundurma yükümlülüğü, alıcının "al ya da öde" yükümlülüğü, doğal gazın satış fiyatının belirli şartların oluşması halinde revizyonu, hasar ve riske ilişkin hükümler, mücbir sebep ve ifa zorlukları, sorumluluğun sınırlandırılması, uyuşmazlıkların çözüm mekanizması ve uygulanacak hukuktur.

Sözleşmelerde özellikle miktar ve fiyat riskinin taraflar arasında dengeli bir şekilde paylaştırılması önem arz etmektedir. Doğal gazın fiyatı belirli bir teslim noktasında belirlenen fiyattır. Teslim noktasına kadar, genellikle doğal gazın üretimi, taşınması ve teslimine ilişkin masraflar satıcı tarafından karşılanarak fiyata yansıtılmaktadır. Öte yandan, alıcı miktar riskine katlanmak zorundadır ki bu durum, yukarıda belirttiğimiz üzere "al ya da öde" hükmü olarak sözleşmelerde yer almaktadır.

Doğal gaz alım ve satım sözleşmelerinde, fiyat revizyonuna ilişkin hükümler diğer bazı hükümlerle birlikte bir bütün oluşturmaktadır. Bunlar, mücbir sebep ve aşırı ifa güçlügü ile ilgili hükümler, sözleşmelerin fiyat ile ilgili hükümleri veya "al ya da öde" yükümlügüü getiren hükümlerdir. Sözleşmenin değişen koşullara göre uyarlanması için müzakere yapılmasını öngören hükümler bu kapsamda büyük önem taşımaktadır. Örneğin, fiyat revizyonu bağlamında, fiyatın değişen koşullara göre revize edilmesi, sözleşmedeki "al ya da öde" yükümlülüğü gibi tarafların yükümlülüklerine ilişkin diğer tüm hükümler dikkate alınarak gerçekleştirilmektedir.

\section{Fiyat Formülü ve Fiyat Revizyonuna İlişsin Hükümler}

Uzun dönemli doğal gaz alım ve satım sözleşmelerinde fiyat genellikle petrol ve petrol ürünlerine dayalı belirli bir formüle dayanmaktadır. Gazın gaz

12 Uygulamada doğal gaz satım sözleşmeleri İngilizce "natural gas sale and purchase agreement" olarak adlandırılmaktadır. Bu nedenle, çalışmamızda bu tür sözleşmeler için "doğal gaz alım ve satım sözleşmeleri" deyimini kullanmanın uygun olduğuna karar vermiş bulunuyoruz. 
ile rekabetinin söz konusu olduğu pazarlarda ise fiyat, genellikle ilgili pazarda geçerli olan $h u b^{13}$ fiyatına endekslidir.

Uzun dönemli doğal gaz alım ve satım sözleşmeleri, fiyat revizyonu veya fiyatın yeniden görüşülmesine ilişkin hükümler içermektedir. Bu hükümler, belirli durumların genelde alıcının pazarında oluşması halinde periyodik dönemlerde taraflardan herhangi birine fiyat değişikliğini talep etme hakkı vermektedir. Bu hükümler ile amaçlanan, sözleşmenin imzalanması sırasında taraflar arasında ekonomik dengenin sözleşme süresi boyunca korunmasını sağlamaktır (restoring economic balance). Dolayısıyla, bu tür hükümlerin asıl hedefinin, pazar koşullarının değişmesi halinde orijinal ekonomik dengeyi sağlama yükümlülüğü getirerek tarafların korunmasını ve sözleşmenin devamlılığını sağlamak olduğu söylenebilir. Bununla birlikte, fiyatta bazı parametrelerin değişmesi sonucu otomatik olarak yapılan düzeltmeler fiyat revizyonu olarak nitelendirilmemektedir. Fiyat revizyonunda önemli olan husus tarafların kontrolü ve öngörüleri dışında meydana gelen değişikliklerdir. Örneğin, sözleşmenin imzalanması sırasında petrol fiyatının uzun bir süre belirli seviyede kalacağı öngörülerek fiyata bir üst sınır veya alt sınır getirilmiş veya tüketimin normal şartlar altında belirli bir seviyede olacağı öngörülmüş ve tüm yükümlülükler buna göre belirlenmiş olabilir. 2020 yılının başında küresel olarak derin etkiler yaratan Covid 19 salgını nedeniyle enerji piyasalarında yaşanan beklenmedik daralma sonucunda ${ }^{14}$ petrol ve dolayısıyla doğal gaz fiyatlarında yaşanan düşüşler bu kapsamda değerlendirilebilir. Aynı şekilde, yaşanan bir kriz sonucu (örneğin savaş hali) petrol üretiminde fiyatın belirli bir seviyenin üzerine çıkması ve buna bağlı

$13 H u b$ fiyatlama, gazın gazla rekabetinin söz konusu olduğu piyasalarda veya spot piyasalarda doğal gaz için geçerli fiyatlandırmadır. Ulusal Dengeleme Noktasının (National Balancing Point-NBP) Birleşik Krallık'ta doğal gaz için sanal bir ticaret yeri olarak ortaya çıkmasıyla İngiltere doğal gaz için fiziksel olmayan sanal bir merkez yaratmıştır. Bu model Belçika (Zeebrugge), Hollanda (Title Transfer Facility -TTF), Fransa (Point d'Echange de GazPEG), Almanya (Net Connect Germany-NCG ve Gaspool-GSL), İtalya (Punto di Scambio Virtuale-PSV) ve diğer piyasalar tarafindan takip edilmiştir. Bkz. https://www.oxfordenergy.org/wpcms/wp-content/uploads/2015/09/NG-101.pdf (Edinim Tarihi: 04.09.2020)

Günümüzde çoğu Avrupa ülkesinde, gaz hub fiyatlandırmasına göre satın alınmaktadır. Ayrıntılı bilgi için bkz. https://energypost.eu/hub-based-pricing-reshaping-eu-gas-marketeven-spain/, (Edinim Tarihi: 03.09.2020)

14 Uluslararası Enerji Ajansının (UEA) Covid 19 nedeniyle enerji piyasalarında yaşanan değişiklikleri içeren 2020 raporu için bkz. https://www.iea.org/topics/covid-19. Ayrıca UEA Başkanı Fatih Birol'un Covid 19 nedeniyle enerji piyasalarında yaşanan daralmaya ilişkin demeci için bkz. https://www.enerjigunlugu.net/birol-talebin-dusmedigi-tekteknoloji-yenilenebilir-enerji-37470h.htm. 
olarak doğal gaz fiyatlarında yaşanan ani artışlar, taraflara sözleşmede yer alan yükümlülükleri ve fiyatı gözden geçirip değiştirme hakkı tanımaktadır. Bu durum, Covid 19 örneğindeki gibi küresel düzeyde veya alıcının pazarına özgü olabilir. Sözleşmede ayrıntılı ve öngörülebilecek tüm riskleri içeren fiyat revizyonuna ilişkin bir hüküm ile, taraflar fiyatta değişiklik yapılmasını talep etme hakkına sahip olduklarında ve buna uygun olarak sözleşme değişen koşullara uyarlandığında, fiyat revizyonu hükmü sözleşmedeki diğer yükümlülüklerle birlikte ele alınarak her iki tarafı koruyucu bir denge sağlanmış olacaktır.

Fiyat revizyonuna ilişkin hükümlerin, tarafların fiyatın revizyonunu talep etme şartlarını ve şartların gerçekleşmesi halinde izleyecekleri yolları da içerdiği görülmektedir. Bu kapsamda, genellikle, taraflara ortalama altı ay veya daha kısa olarak belirlenen bir süre için uyuşmazlığı müzakere etme yükümlüğü getirilmekte, öngörülen süre içerisinde bir anlaşmaya varılamaması halinde taraflara uyuşmazlığı sözleşmede yer alan uyuşmazlık çözüm mekanizmasına sunma hakkı tanınmaktadır. Hemen belirtelim ki, doğal gaz alım ve satım sözleşmelerinde, uyuşmazlıkların çözümü için genellikle uluslararası tahkim yolu tercih edilmektedir.

Fiyat revizyonuna ilişkin hükümlerin esas itibariyle dört aşamadan oluştuğu görülmektedir: Fiyat revizyonunu gerekli kılan şartlarının oluştuğuna ilişkin tetikleyici unsur (trigerring), bildirim yapma (notice) yükümlülüğü, müzakere etme (negotiation) yükümlülüğü ve mutabakat sağlama veya sağlanamaması halinde tahkim yoluna başvurma.

Enerji Şartı Sekreterliğinin petrol ve doğal gaz sözleşmelerinde fiyat mekanizmasına ilişkin raporunda ${ }^{15}$ gösterge niteliğinde yer alan fiyat revizyonu hükmü, genel olarak doğal gaz alım ve satım sözleşmelerinde yer alan fiyat revizyonu hükümlerini yansıtmakta olup sözü edilen dört aşamayı da içermektedirr ${ }^{16}$.

\section{Al ya da Öde Yükümlüğü Getiren Hükümler}

Çalışmamızın başında uzun dönemli olduğunu vurguladığımız uluslararası doğal gaz alım ve satım sözleşmelerinin, ortalama 20-25 yıl gibi

15 Putting a Price on Energy, International Pricing Mechanism for Oil and Gas, Energy Charter Secretariat, 2007.

https://www.energycharter.org/fileadmin/DocumentsMedia/Thematic/Oil_and_Gas_Pricin g_2007_en.pdf, (Edinim Tarihi: 03.09.2020).

16 Putting a Price on Energy, International Pricing Mechanism for Oil and Gas, s. 155. Ayrıca bkz. aşa. dn. 22. 
bir dönemi kapsadığg görülmektedir. Yine daha önce belirtildiği üzere, doğal gazın üretiminin ve taşınmasının sermaye yoğun bir faaliyet olması nedeniyle bu konudaki yatırımların ekonomik değeri de ihmal edilemeyecek boyutta önem taşımaktadır. Dolayısıyla, bu sözleşmelerde satıcının yatırımının karşılığı olarak, alıcıya asgarî miktarda yıllık (bazı sözleşmelerde günlük ve aylık miktarları da içeren) doğal gaz alması yükümlülüğü getirilmektedir. Satıcıya sağlanan bu güvence, sözleşmede yer alan "al ya da öde hükmü" ile düzenlenmektedir. Bununla birlikte, bu yükümlülük, satıcıdan kaynaklanan nedenlerle doğal gazın teslim edilememesi ya da mücbir sebep hallerinde ve LNG $^{17}$ (Liquefied Natural Gas- Sıvılaştırılmış Doğal Gaz) kargoların teslimatında yaşanan gecikmeler gibi durumlarda esnetilebilmektedir. Taraflar, zaman zaman piyasa şartlarını dikkate alarak, doğal gazın alternatif pazarlara teslimatını da öngörmüş olabilirler. Bu durum, genellikle LNG kargolarında söz konusu olmaktadır. Alıcının iç pazarında doğal gaz ihtiyacının olmaması halinde daha kârlı pazarlara teslimat yapılarak taraflar arasında kâr paylaşılmakta ve yapılan teslimat da alıcının alım yükümlülüğünden düşülmektedir.

Doğal gaz alım ve satım sözleşmelerinde "al ya da öde" hükümleri genellikle şu şekilde ifade edilmektedir: "Sözleşmede yer alan hükümlere tâbi olarak Satıcı, Alıcıya doğal gazı satma ve teslim etme ve Alıcı doğal gazı Satıcıdan satın almayı ve teslim almayı kabul eder. Alıcı hazır olan gazl almazsa kararlaştırılmış bir gaz miktarı için ödeme yapar" "18. "Al ya da öde" ile ilgili hükümlerin amacı, doğal gazın üretimi ve satışına ilişkin riskleri alıcı ve satıcı arasında paylaştırmaktır. Satıcı üretim riski yanında fiyat riskini taşımaktadır. Satıcının üstlendiği bu riske karşılık alıcı da asgari miktarda gaz almayı, almadığı takdirde ise belirli oranda bedelini ödemeyi kabul etmekte ve bedeli ödenen ancak alınamayan gaz sonraki yıllarda ilave alımlarla telafi edilmektedir. Bu kapsamda alıcı piyasa talebi riskini taşımaktadır. "Al ya da öde" hükmü ile gaz talebi düşse dahi satıcının her yıl teslimatı kararlaştırılan sözleşme miktarı kadar doğal gazı alması mümkün kılınmaktadır ${ }^{19}$.

17 Sivılaştırılmış doğal gaz (LNG), nakliye ve depolama için yaklaşık $-260^{\circ}$ Fahrenhayt'ta sıvı halde soğutulmuş doğal gazdır. Sıvı haldeki doğal gazın hacmi, gaz halindeki hacmine göre yaklaşı 600 kat daha küçüktür. LNG'nin ayrıntılı tanımı için bkz. https://www.eia.gov/energyexplained/natural-gas/liquefied-natural-gas.php. (Edinim Tarihi: 04.09.2020)

18 Genellikle İngilizce olarak hazırlanan sözleşmelerde söz konusu hüküm şu şekilde ifade edilmektedir: "Subject to the terms and provisions hereof, Seller agrees to sell and deliver to Buyer and Buyer agrees to purchase and receive from Seller, or if available and not taken, pay for that quantity of pipeline gas [an agreed amount of gas]". McARTHUR, J.B.: "The Take-or-Pay Crisis: Diagnosis, Treatment, and Cure for Immorality in the Marketplace”, New Mexico Law Review 1992, Vol. 22, No. 2, s. 358.

19 McARTHUR, s. 358-360. 


\section{§ 2. DOĞAL GAZ ALIM VE SATIM SÖZLEŞMELERİNIN YENIDEN MÜZAKERESİ}

Giriş kısmında ifade ettiğimiz üzere, doğal gaz alım ve satım sözleşmelerinin yeniden müzakeresi esasen sözleşmede yer alan hükümler vasıtasıyla mümkün olabilmektedir. Sözleşmede yeniden müzakereye imkân veren bir hüküm yoksa, o zaman sözleşmedeki mücbir sebep ve aşırı ifa güçlüğüne ilişkin diğer hükümlerden yararlanıldığı görülmektedir. Bununla birlikte, her iki durumda da sözleşmeye uygulanacak hukuk kapsamında yeniden müzakerenin mümkün olup olmayacağ 1 , mümkün ise hangi koşullarda ve hangi esaslara dayanarak bu müzakerenin gerçekleşeceği belirlenecektir.

Doğal gaz alım ve satım sözleşmelerinde yeniden müzakere, esasen fiyat revizyonu ve yeniden müzakereyi düzenleyen genel bir revizyon hükmü olarak karşımıza çıkmakta ve bu hükümler vasıtasıyla özellikle sözleşme fiyatının ve "al ya da öde" yükümlülüklerinin revizyonu mümkün olabilmektedir.

\section{Sözleşmede Fiyat Revizyonu veya Yeniden Müzakereye İlişkin Genel Bir Hükmün Bulunması}

Uzun süreli doğal gaz alım ve satım sözleşmelerinde fiyatın revizyonu hükmü ve ürün paylaşım sözleşmeleri veya imtiyaz sözleşmelerinde ekonomik şartların değişmesi nedeniyle orijinal sözleşme dengesinin tekrar kurulmasına ilişkin hükümler bu kapsamda değerlendirilmektedir ${ }^{20} . \quad G a s$ Natural Aprovisionamientos $v$ Atlantic LNG Co. of Trinidad Tobago ${ }^{21}$ tahkimine konu uyuşmazlık Atlantic $L N G$ 'nin satıcı ve Gas Natural'in alıc1 olduğu 20 yıllık LNG tedarikine ilişkin bir sözleşmeden doğmuştur. İspanya, gaz için birincil pazar olmasına rağmen, sözleşme, alıcının İspanya veya

20 Örneğin, Katar'ın 1994 tarihli Model Ürün Paylaşım Sözleşmesindeki," Sözleşme Dengesi (Equilibrium of the Agreement)" başlı̆̆ını taşıan 34.12 maddesinde yer alan hüküm, yeniden müzakere hükmünün klasik örneklerinden biridir. Bu hükümde, sözleşmenin yürürlüğe girmesinden sonra hukukta, kararlarda ve düzenlemelerde meydana gelen veya gümrük vergilerindeki artış nedeniyle yüklenicinin mali durumunda sözleşmenin imzalandığ 1 andaki durumuna göre olumsuz bir değişim söz konusu olursa tarafların dürüstlük kuralları kapsamında bu hususu yeniden müzakere ederek âdil bir çözümü ve sözleşme dengesini yeniden sağlayacakları ifade edilmektedir. Söz konusu hükümde tarafların anlaşamamaları halinde uyuşmazlığın tahkime sunulacağı da belirtilmektedir.

21 Karar için bkz. WL 4344525 (Southern District of New York 2008), $\mathrm{http}$ ://newyorkconvention1958.org/index.php?lvl=notice_display\&id=1055\&opac_view $=6$ , (Edinim Tarihi: 03.09.2020) 
İngiltere'deki tesislerden herhangi birine gaz taşıyabileceğini içermektedir. Sözleşmenin fiyat formülündeki temel fiyat, bazı Avrupa petrol ürünlerine endeksli bir taban fiyat esas alınarak belirlenmiştir. Her iki taraf da, belirli ön koşulların yerine getirildiğinin tespit edilmesi halinde bu formülün yeniden müzakere edilmesini talep edebilme hakkına sahiptir. Sözleşmenin fiyat revizyonuna ilişkin 8.5. maddesinde, sözleşme imzalandıktan sonraki herhangi bir zamanda tarafların kontrolü dışında meydana gelen değişiklikler nedeniyle tarafların imza aşamasındaki makul beklentileri ile karş1laştırıldığında ekonomik koşulların önemli ölçüde değişmesi ve sözleşme fiyatının değerinde bir azalma olması halinde taraflardan her birine fiyat revizyonu talep etme hakkı tanınmaktadır. Tarafların âdil ve hakkâniyete dayanan bir revizyon üzerinde altı aylık bir süre içerisinde anlaşamamaları halinde konu tahkime sunulabilecektir ${ }^{22}$.

İspanya'da doğal gaz fiyatları düştüğünde, alıcı daha cazip bir pazar olan İngiltere piyasasında yeniden satış yapmaya başlamıştır. Satıcı, alıcı tarafından yeniden satışta elde edilen daha büyük kârdan kendisine düşen payı alabilmek için fiyat formülünde artış yönünde bir revizyon talep etmiştir. Tarafların anlaşamaması üzerine konu Atlantic LNG tarafindan tahkim yargısına taşınmıştır. Hakem heyeti, alıcının son kullanıcı pazarının, gazın hedefine bağlı olarak İspanya veya İngiltere olduğunu belirleyerek iki kısımlı bir fiyat mekanizması oluşturdu. İspanya pazarı için fiyat formülü korunarak temel fiyatta indirim yapılmış ancak alıcının İngiltere piyasası doğal gazın belirli bir yüzdesini yeniden satmaya karar verdiği dönemler için fiyat formülüne belirli bir değer eklemiştir. Bu yeni fiyat yapısı ile geriye dönük bir indirim nedeniyle Atlantic LNG, Gas Natural'e yaklaşık 70 milyon ABD Doları ödemek zorunda kalmıştır. Kararın iptali için Amerikan Federal Mahkemesine yaptığı başvuruda satıcı sözleşmeyi etkili bir şekilde yeniden yazan ve iki parçalı bir fiyatlandırma planı oluşturan hakemlerin yetkilerini

22 Söz konusu madde doğal gaz alım ve satım sözleşmelerinde yer alan tipik bir maddedir ve İngilizce olarak şu şekilde ifade edilmektedir: "If at any time either Party considers that economic circumstances in Spain beyond the control of the Parties, while exercising due diligence, have substantially changed as compared to what it reasonably expected when entering into this Contract . . . and the Contract Price resulting from application of the [original price formula] does not reflect the value of Natural Gas in the Buyer's end user market, then such Party may. . . request that the Parties should forthwith enter into negotiations to determine whether or not such changed circumstances exist and justify a revision of the Contract Price provisions and, if so, to seek agreement on a fair and equitable revision of [the contract price].

Failing agreement on a new formula within six months, either party could submit the matter to arbitration

for decision in accordance with the criteria set out in the 'price reopener' provision." 
aştığını iddia etmiştir. Satıcıya göre, ikili yapı tarafların orijinal pazarlığını bozmuştur. Mahkeme satıcının talebini reddederek sözleşmede "adil ve hakkaniyetli bir revizyon" (fair and equitable) sağlayan geniş bir sözleşme dili olduğunu ve tarafların ikili fiyatlandırma yapısı hakkında hakemlerin yetkisini açıkça sınırlamadıklarını ifade etmiştir ${ }^{23}$.

\section{Sözleşmede Fiyat Revizyonu veya Genel Bir Yeniden Müzakere Hükmünün Bulunmaması}

Sözleşmede ekonomik dengenin değişen şartlar nedeniyle bozulması halinde sözleşme hükümlerinin yeniden müzakere edilmesine veya fiyatın revize edilmesine ilişkin hüküm bulunmaması halinde, diğer sözleşme hükümleri de göz önüne alınarak uygulanacak hukukun denetiminde yeniden müzakere ve uyarlama mümkündür ${ }^{24}$. Böyle durumlarda, yeniden müzakere isteyen taraf, genellikle sözleşmede yer alan mücbir sebep (force majeure) veya uluslararası sözleşme hukukunda aşırı ifa güçlüğü (hardship) olarak ifade edilen doktrine dayanmaktadır.

\section{A. Mücbir Sebep}

Mücbir sebep taraflarca öngörülemeyen, kaçınılamayan ve tarafların kontrolleri dışında gerçekleşen olaylar nedeniyle sözleşmenin ifasını geçici veya sürekli olarak imkânsızlaştıran hallerdir ${ }^{25}$. Dolayısıyla mücbir sebep halleri sözleşmede yer alan yükümlülükleri askıya alan veya sonlandıran hallerdir. Mücbir sebep hükümleri, mücbir sebebe maruz kalan tarafa sözleşmeyi feshetme hakkı vermekle birlikte belirli durumlarda borcu ifa etme yükümlülüğünden kurtarmaktadır ${ }^{26}$.

Doğal gaz alım ve satım sözleşmesinin esasına uygulanacak hukuk olarak Türk hukukunun belirlenmesi halinde gerek mücbir sebebe ilişkin gerek aşırı ifa güçlüğüne ilişkin sözleşme hükümleri Türk hukuku kapsamında değerlendirileceği için konuya ilişkin Türk hukukundaki düzenlemelere kısaca yer vermenin uygun olacağı kanısındayız.

23 PARK, W.: "Gaps and Changed Circumstances in Energy Contracts: The Devil in the Detail", Journal of World Energy Law \& Business 2015, Vol. 8, No. 2, s. 91-92.

24 HORN, N.: "Procedures of Contract Adaptation and Renegotiation in International Commerce", Adaptation and Renegotiation of Contracts in International Trade and Finance, Antwerp, Boston, London, Frankfurt 1985, s. 173 vd.; Peter, s. 130.

25 PETER, s. 235.

26 STROCHBACH, H.: "Force Majeure and Clauses in International Commercial Contracts and Arbitration: The East-German Approach", Journal of International Arbitration 1984, Vol. 1. No. 1, s. 40. 
Türk hukukunda mücbir sebebi düzenleyen genel bir hüküm bulunmadığından, mücbir sebep ifa engelleri başlığında borcu sona erdiren ifa imkânsızlığı kapsamında ele alınmaktadır. Bu bakımdan borcun doğumuna engel olan ve baştan itibaren var olan borcun konusundaki imkânsızlıktan ayrılmaktadır. Başlangıçtaki imkânsızlık sözleşmenin kesin hükümsüz olmasına yol açmaktadır (Türk Borçlar Kanunu ${ }^{27}$ (TBK) m. 27) ${ }^{28}$. Türk hukukunda sonradan ortaya çıkan imkânsızlık borcu sona erdirmektedir. Kusurlu olması halinde borçlu, ifa etmeme nedeniyle alacaklının zararını tazmin etmekle yükümlüdür. (TBK m. 112). Buna karşıllık, borçlunun sorumlu olmadığı imkânsızlık (TBK m. 136) mücbir sebep olarak değerlendirilmektedir ${ }^{29},{ }^{30}$. Bu kapsamda borcun ifasının imkânsız hale gelmesinde imkânsızlık sözleşme imzalandıktan sonradan ortaya çıkmış ve imkânsızlıkta borçlunun kusuru yoksa, borçlunun sorumluluğu ortadan kalkmakta, yani borç sona ermektedir (TBK m. 136/I). Ancak, imkânsızlığın objektif olması, yani borcun hiçbir şekilde ve bir başka kişi tarafından da ifasının mümkün olmaması gerekmektedir ${ }^{31}$. Borcun ifası sadece borçlu açısından imkânsız hale gelmiş ise sübjektif imkânsızlıktan bahsedilir ki burada teknik anlamda bir imkânsızlık değil ifanın güçleşmesi söz konusudur ${ }^{32}$.

Doğal gaz alım ve satım sözleşmelerine baktığımızda, mücbir sebep halleri mücbir sebebe maruz kalan tarafın kontrolü dâhilinde olmayan, makul ve basiretli işletmeci olarak davranmasına ve tüm tedbirleri almasına rağmen kendi yükümlülüklerini yerine getirmede başarısız olmasına neden olaylar olarak ifade edilmektedir. Sözleşmelerde genellikle mücbir sebep olayları

27 RG. 04.02.2011-27836.

28 SEROZAN, R.: İfa, İfa Engelleri, Haksız Zenginleşme (Kocayusufpaşaoğlu/Hatemi/ Serozan/Arpacı,A: Borçlar Hukuku Genel Bölüm, C.3), B. 7, Filiz Kitabevi, İstanbul 2016, s. 164, 166; KILIÇOĞLU, s. 1073; EREN, s.1453.

29 KILIÇOĞLU, s. 1074; EREN, s. 1456; SEROZAN, s. 188-189.

30 Öğretide mücbir sebebin unsurları olarak, mücbir sebep olayı, bu olayın harici olması, olayın kaçınılmaz ve öngörülmez olması, mücbir sebep nedeniyle borcun imkânsız hale gelmesi ve mücbir sebep ile borcun ifa edilmemesi arasında uygun illiyet bağının olması aranmaktadır: EREN, s. 629-633; SEROZAN, s. 188-189; ŞAHIN, H.: Mücbir Sebep Nedeniyle Borcun İfa Edilmemesi, Yetkin Yayınları, Ankara 2019, s. 93-103.

31 Aynı yönde bkz. EREN, s. 1453; KILIÇOĞLU, s. 1074, Karş. OĞUZMAN, K./ÖZ,T.:Borçlar Hukuku Genel Hükümler, C. 1, 17. B, Vedat Kitapçılık, İstanbul 2019, s. 587; SEROZAN, s. 185. Yazarlara göre ifa imkânsızlığı açısından imkânsızlığın objektif veya sübjektif olmasının önemi bulunmamaktadır.

32 KILIÇOĞLU, s. 1074. AEPLI ve von BÜREN gibi bazı yazarlar subjektif imkânsızlı̆̆ın yaptırımının imkânsızlık değil borçlunun temerrüdü olduğunu ileri sürmektedir. Bkz. EREN, s. 1454; SEROZAN, s. 186. 
örnek olarak sayılmaktadır. Bu kapsamda doğal afetler olan yangın, deprem, patlama, sel ve salgınları; ithalat ve ihracat yasakları gibi hukukî sınırlamaları ve savaş, terörist faaliyetler gibi olaylar mücbir sebep kapsamında sayılmakta; ancak daha sonrasında genel bir ifadeye yer verilmektedir. Sözleşmelerde ayrıca alıcı ve satıcıya ait özel haller de sıralanabilmektedir. Bu kapsamda alıcının ve satıcının tesislerinde ve alıcının müşterilerinde yaşanan belirli sorunlar da bu olaylara dâhil edilebilmektedir. Mücbir sebep halinde belirli bir süre içerisinde karşı tarafa bildirim yapılması öngörülerek mücbir sebebin etkisinin ortadan kaldırılmasına ilişkin alınan tedbirlerin açıklanması aranmaktadır. Sözleșmelerde mücbir sebep olaylarının etkilerinin belirli süre devam etmesi ve teslimatın yapılamaması halinde müzakere etme veya sözleşmenin feshi gibi seçenekler de yer alabilmektedir. Bu tür sözleşmelerde, ödemeler ve mali sikıntılar da mücbir sebep kapsamında değerlendirilmemektedir.

Türk hukukunda borcun ifasının imkânsızlaşmasından borçlunun sorumlu olmadığ 1 bu gibi hallerde, bir tarafin borcunun ifası imkânsızlaştı̆̆ 1 için borç sona erecek ve karşı taraf da borcundan kurtulacaktır (TBK m. 136/II). Borcunun ifası imkânsızlaşan borçlu, alacağını önceden tahsil etmişse elde ettiği kazanmayı sebepsiz zenginleşme hükümlerine göre iade edecektir.

Türk hukuku bakımından, karşılıklı edimler içeren sözleşmelerde imkânsızlıktan sorumlu olmayan borçlunun tazminat ödeme yükümlülüğü olmasa da, imkânsızlığın ekonomik etkisi borçlunun üzerindedir. Bununla birlikte, sözleşme ile aksi kararlaştırılabilir. Örneğin, borçlu borcundan kurtulmasına rağmen alacaklının edimi ifa edeceği sözleşmede kararlaştırılmış olabilir ${ }^{33}$.

Borcun ifas1, borçlunun sorumlu olmayacağı nedenlerle kısmen imkânsızlaşırsa, borçlu borcunun sadece kısmen imkânsızlaşan kısmından kurtulur (TBK m. 137) ${ }^{34}$.

Sonradan ortaya çıkan imkânsızlığa yol açan durumun (mücbir sebep) geçici olması halinde burada imkânsızlıktan değil borçlunun kural olarak TBK. m. 117 vd. kapsamında kusursuz temerrüt hali söz konusu olup, alacaklı bu durum (mücbir sebep) sona erene kadar temerrüde düşmüş borçludan aynen ifayı talep edemez ${ }^{35}$.

OĞUZMAN/ÖZ, s. 591-592.

OĞUZMAN/ÖZ, s. 595; EREN, s. 1169; KILIÇOĞLU, s. 1081; SEROZAN, s. 194.

35 SEROZAN, s. 186; ÖZÇELİK, B.Ş.: Borçlunun Sorumlu Olmadığı Sebeplerle Borcun İfa Edilmemesi ve Mücbir Sebep Kayıtları, Basılmamış Doktora Tezi, Ankara Üniversitesi Sosyal Bilimler Enstitüsü, Ankara 2009, s. 71; ŞAHİN, s. 119. 


\section{B. Aşırı İfa Güçlüğü}

Doğal gaz alım ve satım sözleşmelerinde yer alan aşırı ifa güçlügüne ilişkin hükümler de mücbir sebep gibi taraflardan birinin değişen koşullar nedeniyle edimin ifasında uğradığı zararın azaltılmasını amaçlamaktadır. Aşırı ifa güçlüğü söz konusu olduğunda, sözleşmenin uyarlanması veya sona erdirilmesi sonuçları ortaya çıkmaktadır.

Aşırı ifa güçlüğü konusuna öncelikle, Türkiye'nin de taraf olduğu Milletlerarası Mal Satımına İlişkin Sözleşmeler Hakkında Birleşmiş Milletler Antlaşmas ${ }^{36}$ (Viyana Satım Sözleşmesi) kapsamında değinilmesinin isabetli olacağı kanaatindeyiz. Yeknesak bir sözleşmeye aykırılık anlayışını benimsemiş olan Sözleşme, sorumsuzluk hallerini de yeknesak olarak ele almış ve sözleşmeye aykırılığın türüne göre bir ayırım yapmaksızın 79 . maddesinin ilk paragrafında temel sorumsuzluk halini düzenlemiştir ${ }^{37}$. Söz konusu hüküm uyarınca "Taraflardan biri, yükümlülüklerinden birini ifa etmemesinin, denetimi dışında kalan bir engelden kaynaklandığını ve bu engeli, sözleşmenin kurulması anında hesaba katmasinın veya engelden ve sonuçlarından kaçınmasının veya bunları aşmasının kendisinden makul olarak beklenemeyeceğini ispatlaması halinde ifa etmemeden dolayı sorumlu tutulmaz”. Viyana Satım Sözleşmesinde, Uluslararası Ticarî Sözleşmelere ilişkin UNIDROIT kurallarının m. 6.2.1'de yer aldığı gibi aşırı ifa güçlüğüne ilişkin bir hüküm bulunmamaktadır. Sözleşme mücbir sebep veya aşırı ifa güçlügünden ${ }^{38}$ bahsetmemekte, ancak 79 . maddesinde taraflardan birinin yükümlülüklerini ifa etmemesinin, denetimi dışında kalan bir engelden (impediment) kaynaklanması halinde ilgili tarafın sorumlu olmayacağını düzenlenmektedir. Sözleșmenin hazırlığ 1 aşamasında ekonomik zorlukların sorumluluktan kurtarıp kurtarmayacağı hususu tartışmalı olmakla birlikte ${ }^{39}$

361980 UN Convention on Contracts for the International Sale of Goods (CISG). Türkiye Sözleşmeyi onaylamıştır: RG. 7.4.2010-27545. Sözleşmenin 99. maddesinin ikinci fikrası uyarınca, Sözleşme, katılma belgesinin tevdi edildiği tarihten itibaren on iki ayın tamamlanmasını izleyen ayın ilk gününde yürürlüğe gireceğinden, Viyana Satım Sözleşmesi, 1 Ağustos 2011 tarihinden itibaren Türkiye'de de uygulanmaya başlamıştır.

37 Ayrıntılı bilgi için bkz. ATAMER, Y.: Milletlerarası Satım Hukuku, Milletlerarası Mal Satımına İlişkin Sözleşmeler Hakkında Birleşmiş Milletler Antlaşması (CISG), (Ed. Atamer, Y.), "Satıcının Sözleşmeye Aykırı Davranışı Ekseninde CISG'ın Ifa Engelleri Sistemine Genel Bakış", On İki Levha, İstanbul 2008, s. 254.

38 Maddenin Fransız hukukunda geçerli olan emprevizyon teorisi ile Alman hukukundaki işlem temelinin çökmesi teorisi arasında bir yerde olduğu savunulmaktadır: LANDO, O.: "Salient Features of the Principles of European Contract Law: A Comparison with the UCC", Pace International Law Review 2001, Vol. 13, No. 2, s. 367.

39 Viyana Konferansı'nda, Norveç heyeti tarafından sözleşmenin temelinde radikal bir değişiklik olması ve bu durumun borcun ifasını geçici olarak engellemesi halinde borçlunun sorumluluktan kurtulması önerisi reddedilmiştir. Bu durum Sözleşmenin ilk yıllarında 
günümüzde mahkeme ve hakem kararlarında ${ }^{40}$ ve doktrinde anılan maddenin aşırı ifa güçlüğünü kapsadığı kabul edilmektedir ${ }^{41}$. Söz konusu maddenin aşırı ifa güçlüğünü kapsadığını kabul edilse dahi sözleşmelerin uyarlanmasının bu madde kapsamında mümkün olup olmadığı hususu hala tartışmalıdır ${ }^{42}$. Sözleşmede uyarlama konusunda boşluk olduğunu savunan görüş taraftarları bu boşluğunun UNIDROIT ilkeleri madde 6.2.3.(4)'te yer alan uyarlama hükmü ile doldurulmasını savunmaktadır ${ }^{43}$. Bazı yazarlar, bu yöntemin gerekli olmadığını, Viyana Satım Sözleşmesi kapsamında sözleşmenin ihlaline uygulanacak hükümlerin 77. maddede yer alan zararın azaltılması

olunması nedeniyle mantıklı olarak kabul edilmektedir. SCHWENZER, I.: "Force Majeure and Hardship in International Sales Contracts", Victoria University of Wellington Law Review 2008, Vol. 39, No. 4, s. 712-713.

40 Mahkemeler genel olarak sözleşmenin ekonomik dengesinin temel olarak değişmemesi nedeniyle borcun ifasının engellenmediğine karar vermiştir. Örnek kararlar için bkz. CISGonline Case no. 694, http://www.cisg-online.ch/content/api/cisg/display.cfm?test=694, (Edinim Tarihi: 03.09.2020), CISG-online Case no. 436 http://cisgw3.law.pace.edu/ cases/980212 bu.html, (Edinim Tarihi: 03.09.2020). Aynı yönde görüş için bkz.

GARRO, A: "Comparison Between Provisions of the CISG Regarding Exemption of Liability for Damages (Art. 79) and the Counterpart Provisions of the UNIDROIT Principles (Art. 7.1.7)", http://cisgw3.law.pace.edu/cisg/principles/uni79.htm, (Edinim Tarihi: 03.09.2020).

41 SCHWENZER, s. 713; ATAMER, Y. :Borçlunun CISG Madde 79 Uyarınca Tazminat Sorumluluğundan Kurtulması Halinde Alacaklının Diğer Taleplerinin Akıbeti Ne Olur? https://dergipark.org.tr/tr/download/article-file/179440, (Edinim Tarihi: 04.09.2020), s. 509

42 SCHWENZER, s. 712-713; BAYSAL, s. 72.

43 GARRO, http://cisgw3.law.pace.edu/cisg/principles/uni79.htm. Belçika Yüksek Mahkemesi, çelik boru satımını konu alan bir sözleşmeye ilişkin önüne gelen ihtilâfta, sözleşmenin kurulmasından sonra ancak ifasından önce çelik fiyatlarında beklenmedik şekilde meydana gelen \%70'lik artışı değerlendirmiş; bu bağlamda, aşırı ifa güçlüğü meselesinin Antlaşmada düzenlenmediğini, bu meseleye ilişkin bir boşluk olduğunu ve bu boşluğun uluslararası ticaretin genel prensipleri uyarınca doldurulması gerektiğini belirtmiştir: Scafom International BV v. Lorraine Tubes S.A.S. kararı, case no: C.07.0289.N (http:// cisgw3.law.pace.edu/cases/090619b1.html). Ayrıca bkz. AYANOĞLU MORALI, A.: "Milletlerarası Mal Satımına İlişkin Sözleşmeler Hakkında Birleşmiş Milletler Antlaşması'nın Öngördüğ̈̈ Sorumluluktan Kurtulma Sistemi”, Galatasaray Üniversitesi Hukuk Fakültesi Dergisi 2013, S. 1, Milletlerarası Mal Satımına İlişkin Birleşmiş Milletler Anlaşması'nın (CISG) Türk Borçlar Kanunu Çerçevesinde Değerlendirilmesi Sempozyumu Özel Sayısı, s. 296. Karş. AYOĞLU, T.: "Milletlerarası Menkul Mal Satımları Hakkında Viyana Konvansiyonu'nda Boşlukların Doldurulması”, Galatasaray Üniversitesi Hukuk Fakültesi Dergisi 2013, S. 1, Milletlerarası Mal Satımına İlişkin Birleşmiş Milletler Anlaşmasının (CISG) Türk Borçlar Kanunu Çerçevesinde Değerlendirilmesi Sempozyumu Özel Sayısı, s. 87-110, s. 103. Yazar harici boşluk olması nedeniyle boşluğun UNIDROIT kuralları ile doldurulamayacağını savunmaktadır. 
yükümlülüğü ile birlikte ele alındığında tatmin edici ve esnek bir sonuç verdiğini kabul etmektedir ${ }^{44}$.

Viyana Satım Sözleşmesi Danışma Kurulu ise, tarafların Sözleşmenin 7(1). maddesinde saklı olan dürüstlük kuralı kapsamında ${ }^{45}$ sözleşmelerin bozulan dengesinin yeniden oluşturulabileceğini, müzakerelerin olumsuz sonuçlanması halinde sözleşmede mahkeme veya hakemlere sözleşme hükümlerini uyarlama veya revize etmeye yönelik hüküm bulunmamasına rağmen Sözleşmenin 79(5) maddesinde yer alan ${ }^{46}$ hükme dayanarak mahkeme veya hakemlerin değişen şartlara göre sözleşmeyi uyarlayabileceklerini savunmaktadir ${ }^{47}$.

Türk hukukunda, sözleşmenin kurulmasından sonra ortaya çıkan bazı durumlar nedeniyle borçlunun borcunun ifası imkânsızlaşmamış olmakla birlikte, aşırı derecede güçleşmişse sözleşmenin uyarlanması veya sona erdirilmesi söz konusu olacaktır (TBK m. 138) ${ }^{48}$. Özellikle doğal gaz alım ve satım sözleşmeleri gibi sürekli bir sözleşme ilişkisinin söz konusu olduğu hallerde borcun ifasına başlanmışsa ve aşırı ifa güçlüğü sonucu uyarlama da pek mümkün değilse sözleşmenin feshi söz konusu olabilecektir. Bu durumda sözleşme dönmedeki gibi geçmişe etkili olarak değil, fesihten sonrası için ileriye etkili olarak sona erecektir ${ }^{49}$.

Doğal gaz alım ve satım sözleşmelerinde aşırı ifa güçlüğüne ilişkin hükümler, genellikle doğal gaz teslimatını etkileyen ekonomik ve ticarî şartlarda ciddî ve önemli değişikliklerin olması ve bu durumun tarafların

44 SCHWENZER, s. 724

45 AYANOĞLU MORALI, s. 296.

46 Madde 79 (5) şu hükmü içermektedir: "Bu madde, tarafların bu Antlaşma uyarınca tazminat talebi dışındaki herhangi bir hakkını kullanmasını engellemez".

47 Ayrıntılı bilgi için bkz. CISG Advisory Council Opinion No. 7, Exemption of Liability for Damages Under Article 79 of the CISG, https://www.cisg.law.pace.edu/cisg/CISG-ACop7.html, (Edinim Tarihi: 03.09.2020).

48 Uyarlama için dört koşulun gerçekleşmesi gerekmektedir. Her şeyden önce, sözleşme kurulduktan sonra tarafların edimleri arasındaki denge borçludan sonuçları yüklenmesini istenemeyecek kadar büyük ölçüde bozulmalıdır. Bu durum işlem temelinin çökmesi olarak da ifade edilmektedir. İkinci olarak, edimlerin dengesindeki değişiklik, sözleşme yapılırken öngörülemeyen veya öngörülmesi de beklenmeyen olağanüstü bir durumdan ileri gelmelidir. Savaş, ekonomik kriz, devalüasyon, tabii afetler, ithalat ve ihracat kısıtlamaları bu olaylara örnek olarak sayılabilir. Üçüncü olarak, aşırı ifa güçlüğü yaratan olgu borçludan kaynaklanmamalıdır. Nihayet, edimler henüz ifa edilmemiş olmalı veya ifanın aşırı ölçüde güçleşmesinden doğan haklar saklı tutularak ifa yapılmıș olmalıdır: OĞUZMAN/ÖZ, s. 599-601; KILIÇOĞLU, s. 346-348; EREN, s. 545-546; BAYSAL, s. 143-221.

49 OĞUZMAN/ÖZ, s. 602; EREN, s. 544; BAYSAL, s. 243. 
yükümlülüklerini yerine getirmelerinde aşırı yük oluşturması halleri olarak düzenlenmektedir. Sözleşmelerde aşırı ifa güçlüğüne düşen tarafın karşı tarafa bir bildirim yaparak sözleşme şartlarını değişen koşullar nedeniyle revize etme ve görüşme talebinde bulunması yer almaktadır. Tarafların genellikle belirli bir süre içerisinde görüşme yükümlülükleri de bulunmaktadır. Ancak sözleşmelerde genellikle aşırı ifa güçlüğüne ilişkin bir hükmün bulunmasının tarafların yükümlülüklerini etkilemeyeceği ve taraflarca mutabakat olmadığı sürece sözleşmede yer alan hak ve yükümlülüklerin bu hükmün varlığından etkilenmeyeceği belirtilmektedir. Genellikle, aşırı ifa güçlüğü hükmü ile "al ya da öde" yükümlülüğü ve fiyatın revizyonu gibi hususlarda sözleşme değişiklikleri talep edilmektedir.

Aşırı ifa güçlüğü mücbir sebep gibi sözleşmeyi sona erdiren durumları içermez. Aşırı ifa güçlüğü hükümleri, yeni koşullar tarafından değişen sözleşme dengesini uyarlamak için bazı sözleşme hükümlerinin yeniden müzakere edilerek sözleşmede değişiklik yapılmasını amaçlamaktadır ${ }^{50}$.

Sonuç olarak her iki terim arasında farklılık olsa da temel amaçları aynı olup $^{51}$, sözleşmenin değişen koşulları nedeniyle tarafların uğradığı zararı azaltmayı amaçlamaktadır. $\mathrm{Bu}$ konudaki görüşler genel olarak millî hukukların değişen şartlara bakış açısını yansıtmaktadır.

Amerika Birleşik Devletlerinde, 1980'li yıllarda doğal gaz piyasa şartlarında meydana gelen değişiklikler sonucu petrol fiyatlarında büyük değişim olmuş, talepte yaşanan düşüş alıcılar için önemli sorunlar yaratmıştır. Söz konusu problem Federal Enerji Düzenleme Komisyonu'nun (Federal Energy Regulatory Commission) müdahalesi ile daha da karmaşı hale gelmiştir. Komisyon, 380 numaralı Kararı ile piyasayı serbestleştirmek ve piyasada rekabeti artırmak amaciyla boru hattı müşterilerinin "al ya da öde" yükümlülükleri ile bağlı olmadığını bildirirken, 436 sayılı Karar ile boru hattı müşterilerinin istedikleri tedarikçiden doğal gaz alabileceklerine karar vermiştir. Söz konusu Kararlar sonucu düşük fiyatlı yeni bir spot piyasa ${ }^{52}$

50 STROCHBACH, s. 40; SORNARAJAH, M.: "Supremacy of the Renegotiation Clause in International Contracts", Journal of International Arbitration 1988, Vol. 5, No. 2, s. 108.

51 Pratikte her iki terim farklı olsa da uluslararası tahkimde her iki terimin kullanılmasında karışıklık yaşandığı görülmekte ve önemli uluslararası sözleşmelerde eş anlamlı olarak kullanıldıkları belirtilmektedir. Ayrıntılı bilgi için bkz. MELIS, W.: "Force Majeure and Hardship Clauses in International Commercial Contracts in View of the Practice of the ICC Court of Arbitration”, Journal of International. Arbitration 1984. Vol. 1, No. 3, s. 213.

52 Spot Pazar, anında enerji satışı ve teslimatı için gerçek zamanlı bir emtia piyasasıdır. Spot piyasalar, günler ile haftalar arasında bir zaman ölçeğinde işletildikleri doğal gaz ve zaman 
oluşturulmuş ve "al ya da öde" hükmü içeren yüksek fiyatlı sözleşmeler müşteriler için ekonomik varlıklarını koruma anlamında risk oluşturmuştur. Sonuçta alıcılar aleyhine açılan davalarda alıcılar mücbir sebep durumuna dayanmışlar ve Komisyon kararlarına dayanarak ticarî açıdan imkânsızlığı ileri sürmüşlerdir. Ancak mahkemeler alıcılar tarafından yapılan itirazları kabul etmeyerek her piyasa değişikliğinin ve talepteki azalmanın mücbir sebep durumu oluşturmayacağına ve Komisyon kararlarının sözleşmeden kaynaklanan yükümlülüklerin ihlali için gerekçe olmadığına karar vermiştir ${ }^{53}$.

\section{§ 3. UYGULANACAK HUKUKUN ETKİSİ}

Sözleşmenin esasına uygulanacak hukuk sözleşmelerin uyarlanması için kritik öneme sahiptir. Tarafların hangi şartlarda ve kapsamda değişiklik yapabileceklerini belirlemektedir. Uygulanacak hukuk aynı zamanda müzakerelerin olumsuz sonuçlanması ve bu olumsuzluğun taraflardan birinden kaynaklandığı hallere de sonuçlar bağlamaktadır ${ }^{54}$.

Taraflarca uygulanacak hukuk olarak millî bir hukuk seçildiğinde hakemler tarafların iradesine uygun olarak bu hukuku uygular. Tarafların uluslararası hukuku tek başına seçmeleri halinde veya millî hukuk, uluslararası hukuk, hukukun genel prensipleri ve ticarî örf âdeti bir bütün olarak seçmesi halinde büyük sıkıntılar ortaya çıkmakta ve hakemlerin uyuşmazlığa uygulanacak hukuk kurallarını tayin etmeleri zorlaşmaktadır. Hakemler bu durumda seçilen tüm kuralları değerlendirerek ortak olan hükümleri uygulamayı tercih etmektedir. Söz konusu sistemlerin farklı sonuçlar vermesi halinde ise hakemlerin genel olarak kabul edilen çözümü tercih ettikleri görülmektedir ${ }^{55}$.

Aşağıda, öncelikle farklı hukuk sistemlerinin sözleşmelerinin değişen şartlara göre uyarlanması konusuna bakış açısı, detaya girilmeden genel hatları ile ele alınacaktır.

\footnotetext{
ölçeğinin birkaç dakika kadar küçük olabileceği elektrik piyasası için mevcuttur. Spot piyasalarda enerji için nokta bir pazar yeri yoktur. Spot piyasalar, işlemleri gerçekleştirmek için altyapının bulunduğu her yerde faaliyet gösterebilir. Eskiden fiziksel olarak belirli mekanlarda yürütülen spot pazarların çoğu artık internet üzerinden işletilmektedir: Glossary of terms used in the trading of oil and gas, utilities and mining commodities, https://www. pwc.com/gx/en/energy-utilities-mining/pdf/eumcommoditiestradingriskmanagementglossary. pdf, (Edinim Tarihi: 03.09.2020)

53 McARTHUR, s. $361 \mathrm{vd}$.

54 QURASHI, s. 269.

55 QURASHI, s. 269-270.
} 


\section{Ortak Hukuk (Common Law) Sistemi}

Ortak Hukukta tarafların sözleşme şartlarını yeniden müzakere etme yükümlülükleri ve mahkemenin sözleşmeyi değişen şartlara göre değiştirme yetkisi bulunmamaktadır. Ancak, birçok davada mahkemeler, beklenmeyen hal (frustration) doktrini ${ }^{56}$ kapsamında sözleşme yükümlülüğünden kurtarmayı kabul etmiştir. Bu doktrine göre sözleşme ilişkisi kurulduktan sonra borcun ifa edilmesi tarafların kusuru olmaksızın hukukî veya fiilî olarak imkânsızlaşırsa veya sonradan meydana gelen bir olay sonucu sözleşme şartlarında değişiklik meydana gelirse ve sözleşmenin temeli zedelenirse taraflar yükümlülüklerinden kurtulmakta ve sözleşme ilişkisi sona ermektedir ${ }^{57}$. Kara Avrupası sisteminde ifa imkânsızlı̆̆ı olarak olarak değerlendirilen durum, İngiliz hukukunda beklenmeyen hal ve Amerikan hukukunda elverişsizlik (impractibility) teorileri altında değerlendirilmiştir. Dolayısıyla İngiliz hukukunda beklenmeyen hal (frustration) kavramının bir imkânsızlık teorisi olmasına rağmen İngiliz mahkemeleri frustration doktrinini çok dar bir şekilde yorumlamaktadır. Davaların büyük çoğunluğunda, sözleşmenin değişen koşullara uyarlanmalarını sağlamak için mahkemeler, gerekli esnekliği sağlayan sözleşme hükümlerini kabul etmektedir. Bununla birlikte aşırı ifa güçlüğ̈ İngiliz hukukuna göre tek başına ifay1 engelleyen yeterli bir neden olarak kabul edilmemektedir ${ }^{58}$. İngiliz common law düzeninde sözleşmeye bağlilık ilkesinde 1srar edilmekte, sonradan meydana gelen olaylar külfet getirse bile tarafların sözleşmeyle bağlı kalınması gerektiği kabul edilmektedir.

Amerikan hukukunda, Yeknesak Ticaret Kanunu (Uniform Comercial Code), Bölüm 2-615'de yer alan elverişsizlik doktrinine göre hammadde temininde aşırı kıtlık yaşanması, ana tedarik kaynağında yaşanan beklenmedik duraklama gibi aşırı derecede külfetli edim söz konusu olduğunda uzun süreli sözleşmelerin bu sebepler nedeniyle yeniden müzakere edilmesi de

56 Aynı zamanda sonradan meydana gelen imkânsızlık nedeniyle borcun ifa edilmemesi (supervening impossibility of performance of contracts) olarak da adlandırılmaktadır. Doktrin, temelde İngiliz mahkemeleri tarafından 19. yüzyılın ikinci yarısından sonra geliştirilmiştir: MANIRUZZAMAN, A.F.M.: "State Contracts with Aliens: The Question of Unilateral Change by the State in Contemporary International Law", Journal of International Arbitration 1992, Vol. 9, No. 4, s. 147.

57 GOODE, R.: Commercial Law, Penguin Books, Ed.3, London 2004, s. 136;

McKENDRICK, E.: Contract Law, Palgrave Law Masters, Ed. 4, New York 2000, s. 301; MANIRUZZAMAN, State Contracts with Aliens, s. 147; QURASHI, s. 270-271.

58 GOODE, s. 136-137. 
benimsenmiştir ${ }^{59}$. Restatement (Second) of Contracts ise sözleşme kurulduktan sonra meydana gelen bir olay nedeni ile taraflardan birisinin borcunu ifa etmesi kusuru olmaksızın elverişsiz hale gelirse aksine bir hüküm olmadığı sürece söz konusu taraf borcunu yerine getirme yükümlülüğünden kurtulmaktadir.

İngiliz mahkemeleri beklenmeyen hal teorisine göre değişen şartlar nedeniyle sözleșmeyi yeniden kaleme alma yoluna gitmediği gibi, taraflar sözleşmede özel bir hüküm olmadıkça, sözleşmenin yeni şartlara uyarlanmasını talep hakkına sahip değildir. Amerikan yargı kararları da aynı yönde seyretmektedir ${ }^{60}$.

İngiliz ve Amerikalı hukukçuların yaptıkları sözleşmeler çok daha ayrıntılı hükümler içerdiğinden belirli bir konuda sözleşme hüküm bulunmaması halinde hâkime daha az müdahale yetkisi tanınmaktadır ${ }^{61}$.

\section{Kara Avrupası Hukuk (Civil Law) Sistemi}

Alman hukukunun temelinde sözleşmeye bağlılık ilkesi söz konusu olsa da Alman Medeni Kanununun (BGB) 313. paragrafında işlem temelinin çökmesi düzenlemiştir ${ }^{62}$. BGB 313 paragrafi ile değişen şartları taraflar öngörmüş olsaydı sözleşmeyi hiç veya mevcut içerikte yapmayacak idiyse ve taraflardan birinden sözleşmeyi bu hali ile devam ettirmesinin beklenmemesinin mümkün olmadığı hallerde sözleşmenin yeni koşullara uyarlanmasına imkân verilmektedir ${ }^{63}$ Uyarlama mümkün değilse etkilenen taraf sözleşmeyi geçmişe etkili olarak sona erdirebilmektedir. Ancak sürekli bir borcun ifasına ilişkin sözleşme varsa, sadece ileriye etkili sona erdirme (fesih) söz konusudur ${ }^{64}$. Alman hukukunda, ifa için mâkul ölçülerin ötesinde borçlunun çaba göstermesi gerekiyorsa ifayı reddetmesine imkân

59 QURASHI, s. 271.

60 MANIRUZZAMAN, State Contracts with Aliens, s. 148.

61 PUELINCKX, A.H.: "Frustration, Hardship, Force Majeure; Imprevision; Wegfall der Geschäftsgrundlage; Unmöglichkeit, Changed Circumstances: A Comparative Study in English, French, German and Japanese Law", Journal of International Arbitration 1986, Vol. 3, No. 2, s. 48.

62 Söz konusu hüküm yürürlüğe girmeden önce işlem temelinin çökmesi teorisi BGB 242'de düzenlenen dürüstlük kuralı kapsamında geliştirilmiş bir teoridir: BAYSAL, s. 29.

63 RÖSLER, H. (Çev. AYDIN-ÜNVER, T.):" Alman ve Uluslararası Sözleşme Hukukunda Değişen ve Öngörülemeyen Koşullar”, İÜHFM 2008, C. LXVI, S.1, s. 356; KILIÇOĞLU, s. 344.

64 RÖSLER, s. 356. 
verilmektedir (BGB para. 275) ${ }^{65}$. Makul olma ölçütü, borçlunun göstereceği çabanın alacaklının sözleşmenin ifasındaki çıkarıyla orantısı oranında değerlendirilmektedir ${ }^{66}$. Ancak, 1973 petrol krizi sırasında bir petrol ithalat şirketi, fiyatta uyarlama olmadığı gerekçesiyle ifayı reddetmiştir. Alman Federal Mahkemesi petrol tedarikçisinin uğradığı malî kayıplarda kusurlu olduğunu ve rezerv biriktirmek için daha fazla miktarda satın alma yoluna gitmeyerek ihmalkâr davrandığını ve sözleşmede tarafların petrol fiyatlarındaki değişiklik riskine katlanma niyetlerinin göstergesi olarak sabit fiyatın yer aldığını ve sözleşmenin iki buçuk aylık bir süre sonunda sona erecek olmasını da dikkate alarak uyarlamayı reddetmiştir. Sonuçta tedarikçinin yüksek fiyatla petrolü tedarik etmesine rağmen satışından yüksek miktarda gelir elde etmesi söz konusuydu ve yarar- zarar oranında bir dengesizlik bulunmamaktayd ${ }^{67}$.

Fransız hukukunda da sözleşmeye bağl1lık ilkesi kabul edilmekle birlikte, sözleşmede aksine bir hüküm yoksa sözleşmenin imkânsızlık nedeniyle ifasından kurtulmak, kusurun olmaması şartıyla mümkün kılınmıştır. Mücbir sebep de imkânsızlık kapsamında değerlendirilmektedir. Fransız Danıştayı tarafindan geliştirilen emprevision doktrini ise devlet veya kamu otoriteleri ile imzalanan sözleşmeler için uygulama alanı bulmaktadır. Emprevision doktrini, sözleşmenin ekonomik dengesinin öngörülemeyen olaylar nedeniyle önemli oranda değişmesi halinde mahkemelere sözleşmeleri uyarlama yetkisi vermektedir. Sözleşmenin sona ermesi sözleşmenin ekonomik dengesini etkileyen olayın nihai ve onarılamaz olması halinde söz konusudur. Bu

65 Alman Hukukunda BGB'nin 275 paragrafı ile BGB'nin 313 paragrafı arasındaki ilişki tartışmalıdır. BGB'nin 275 paragrafı çeşitli imkânsızlık hallerini tek çatı altında toplamıştır. BGB'nin 275/I paragrafı fiziksel ifa imkânsızlığını düzenlemektedir. Tartışma, işlem temelinin çökmesini düzenleyen BGB'nin 313 paragrafı ile pratik ifa imkânsızlığını düzenleyen 275/II ve kişisel ifa imkânsızlığını düzenleyen 275/III paragrafları arasındaki yarışmadan kaynaklanmaktadır. Son iki halde BGB'nin 275 paragrafının ilk fikrasından farklı olarak ifa teorik olarak mümkündür. BGB'nin 275/ II paragrafında ise, alacaklının ifadan sağlayacağı çıkarla borçlunun ifayı gerçekleştirmek için harcayacağı çaba arasında aşırı oransızlık söz konusu iken, paragraf 275 III'te ise ortaya çıkan engel ile alacaklının çıkarı karşılaştırılmaktadır. Sonuç olarak ekonomik imkânsızlık BGB'nin 313 paragrafi kapsamında, pratik imkânsızlık ise BGB'nin 275. paragrafı kapsamında değerlendirilmektedir: Bkz. BAYSAL, s. 31-32.

66 Bu konudaki verilen klasik örnek, bir yüzüğün teslimatı için kurulan sözleşmede yüzüğün alıcıya teslim edilmeden göle düşmesi ve dibe batmasıdır. Gölü boşaltarak veya metal detektör kullanarak yüzüğü çıkarmak teknik olarak mümkündür ve sözleşmenin ifası imkânsız değildir. Buna rağmen, yüzüğün çıkarılması için gereken çaba değerinden ve alacaklının çıkarı dikkate alındığında oransızdır.

67 RÖSLER, s. 357-359. 
hüküm, özellikle devletle yapılan uluslararası petrol sözleşmelerinde uygulanmaktadir ${ }^{68}$.

İsviçre hukukunda sözleşmede aksine bir hüküm olmadığı hallerde sonraki imkânsızlık nedeniyle borç sona ermektedir. İsviçre Borçlar Kanununun 119. maddesinde düzenlenen ${ }^{69}$ borçlunun kusuruna dayanmayan imkânsızlık hali, yukarıda izah edildiği üzere ${ }^{70}$ Türk hukuku ile parallelik göstermektedir. İmkânsızlığa sebep olan olayın öngörülemez, önlenemez olması gerekmekte ve tarafların kusurunun olmaması aranmaktadır. Bununla birlikte İsviçre Medeni Kanunun 2. maddesinde yer alan dürüstlük kuralı kapsamında sözleşmelerde değişen şartlar nedeniyle ekonomik dengenin bozulması halinde mahkemelerin sözleşmeleri uyarlama veya sona erdirmesi söz konusu olmaktadır ${ }^{71}$.

\section{Uluslararası Hukuk}

Uluslararası hukukta, değişen koşullar (rebus sic stantibus) ilkesi genel kabul görmektedir. Bu ilke, değişen koşullara ilişkin sözleşmede hüküm olmasa da uygulanmaktadır. 1969 tarihli Viyana Anlaşmalar Hukuku Sözleşmesinin $^{72}$ 62. maddesinde şartların esaslı bir şekilde değişmesinin hukukî etkileri düzenlenmiştir. Buna göre, değişiklikten olumsuz etkilenen taraf, anlaşma yükümlülüklerinden çekilme veya yükümlülüğünü müzakere etme talebinde bulunabilir. Viyana Anlaşmalar Hukuku Sözleşmesi devletler arasında uygulanan bir anlaşma olmakla birlikte, 62. maddenin genel hukukî ilke olarak özel taraflara veya devlet ile özel taraf arasındaki uluslararası

68 QURASHI, s. 272-273; FUCCI, F.: "Hardship and Changed Circumstances as Grounds for Adjustment or Non-Performance of Contracts, Practical Considerations in International Infrastructure and Finance", American Bar Association Section of International Law, Spring Meeting, April 2006; MANIRUZZAMAN, State Contracts with Aliens, s. 152.

69 İngilizce metin için bkz. https://www.admin.ch/opc/en/classifiedcompilation/19110009/202004010000/220.pdf, (Edinim Tarihi: 03.09.2020)

70 Bkz. yuk. s. 15-17.

71 QURASHI, s. 273.

72 İngilizce metin için bkz. https://legal.un.org/ilc/texts/instruments/english/conventions/1_1_1969.pdf, (Edinim Tarihi: 03.09.2020). Türkiye sözlemeye taraf değildir. Ancak, kuralları uluslararası örf ve âdet haline gelen sözleşme hükümleri uluslararası hukukun kaynakları olarak taraf olmayan devletleri de bağlamaktadır: PAZARCI, H.: Uluslararası Hukuk Dersleri, 1. Kitap, Gözden Geçirilmiş 14. B., Turhan Kitabevi, Ankara 2017, s. 259; Gabcikovo v Magymaros (Macaristan v Slovakya) uyuşmazlığında UAD'nın aynı yönde kararı için bkz. https://www.icj-cij.org/files/case-related/92/7377.pdf, (Edinim Tarihi: 03.09.2020) 
ilişkilere uygulanmasının mümkün olup olmadığı konusunda yoğun tartışmalar bulunmaktadır ${ }^{73}$.

Viyana Satım Sözleşmesinin 79. maddesi $\mathrm{de}^{74}$ taraflardan birisinin kontrolü dışında gerçekleşen olaylar nedeniyle, borçlunun borcunu ifa edememesi halinde sorumlu olmayacağı düzenlenmiştir.

Benzer ilkelere dayanan uygulama, uluslararası ticarette birçok sözleşmede yer almakta ve mücbir sebep hükmü olarak tanımlanmaktadır. Sözleşme uygulamalarında bu tarz yazılımlar uluslararası common opinio kapsamında mücbir sebep hali olarak yorumlanmaktadır. Söz konusu uygulama Avrupa Birliği Adalet Divanı kararlarında da görülmektedir ${ }^{75}$. Bununla birlikte uzun dönemli sözleşmelere ilişkin değișen şartlara uyarlama konusunda genel bir uygulama bulunmamaktadır ${ }^{76}$. Sadece fiyat düzenlemesi gibi belirli problemlerde değişen şartlara uyarlama kanun koyucular veya mahkemeler tarafından ortaya koyulan formüllerde görülmektedir. Ancak UNCITRAL Uzlaștırma Kurallari ${ }^{77}$ ve Milletlerarası Ticaret Odası (MTO) ${ }^{78}$ Uyarlama Kuralları ${ }^{79}$ mücbir sebep, aşırı ifa güçlüğü gibi durumların hukuki çerçevesini belirlemeden genel olarak sözleşmelerin müzakere yolu ile uyarlanmasını desteklemektedir. BM Ulusötesi Şirketlere İlişkin İlke Kuralları Taslağ $1^{80}$ hükümetler ve ulusötesi şirketler arasındaki uzun dönemli sözleşmelere revizyon hükmü koymayı önermektedir. Taslak böyle bir hükmün olmaması halinde tarafların dürüstlük kuralı kapsamında sözleşmeyi müzakere edeceklerini belirtmektedir ${ }^{81}$.

Mücbir sebebi ve aşırı ifa güçlüğünü tanıyan ve düzenleyen diğer uluslararası araçlar arasında Uluslararası Ticarî Sözleşmelere İlişkin UNIDROIT Kuralları ${ }^{82}$ da önem taşımaktadır. Söz konusu Kuralların 6.2.1

73 HORN, s. 25.

74 Bkz. yuk. s. 18-19.

75 HORN, s. 27

76 HORN, s. 27

77 United Nations Commision on International Trade Law Conciliation Rules ingilizce metin için https://www.uncitral.org/pdf/english/texts/arbitration/conc-rules/conc-rules-e.pdf, (Edinim Tarihi: 03.09.2020)

78 International Chamber of Commerce, ICC.

79 The UN-ECOSOC Draft Code on Transnational Corporations. Metin için bkz. https://iccwbo.org/content/uploads/sites/3/2020/03/icc-forcemajeure-hardship-clausesmarch2020.pdf, (Edinim Tarihi: 03.09.2020)

80 https://digitallibrary.un.org/record/105591, (Edinim Tarihi: 03.09.2020)

81 HORN, s. 26-27.

82 UNIDROIT Principles of International Commercial Contracts 2016. Metin için bkz. https://www.unidroit.org/instruments/commercial-contracts/unidroit-principles-2016, (Edinim Tarihi: 03.09.2020) 
maddesinde aşırı ifa güçlüğü ve 7.1.7 maddesinde mücbir sebep düzenlemektedir. Kuralların önsözünde taraflarca sözleşmeye uygulanacak hukuk seçilmediği taktirde bu kuralların uygulanabileceği ifade edilmektedir. Aşırı ifa güçlügünün sonuçları, Kuralların 6.2.3 maddesinde düzenlenmiş olup, zarar gören tarafa müzakere etmeyi talep etme hakkı verilmiştir. Müzakerelerin dürüstlük kuralları kapsamında yürütüleceği ve tarafların değişen şartlar nedeniyle sözleşmenin yeni şartlara uyarlama konusunda mutabık olmamaları halinde uyuşmazlığı mahkemeye taşıyabilecekleri ifade edilmektedir. Kuralların mücbir sebep ile ilgili hükmünün yorumu kısmında mücbir sebebin aşırı ifa güçlüğü ile birlikte ele alınması gerektiği ifade edilmektedir. Özellikle, uzun dönemli yatırım sözleşmelerinde yatırımın değerinin ilerleyen yıllarda ortaya çıkacak olması nedeniyle mücbir sebebin ortaya çıktığı durumlarda tarafların sözleşmeyi sona erdirmekten ziyade devam ettirmekte çıkarlarının olduğu ve bu yönde bir eğilim sergileyebilecekleri ve bunun da farklı formlarda ifade edildiğ belirtilmektedir.

MTO, millî kanunlarda yer alan mücbir sebebe ilişkin farklı yaklaşımları ortadan kaldırmak ve sözleşme hazırlayanlara örnek teşkil etmek amacıyla Mart 2020'de mücbir sebebe ilişkin hükmü, kısa ve uzun versiyon şeklinde yeniden yayınlamıştır. Aşırı ifa güçlüğü de aynı şekilde millî hukuklar arasındaki farklılığ müzakere etmelerine imkân tanınmıştır. Tarafların müzakereler sonucunda anlaşamamaları halinde millî hukuklarda yer alan sonuçlara ise, tarafların sözleşmeyi sona erdirmesi, mahkeme tarafından uyarlama veya sona erdirme ve mahkeme tarafından sona erdirme şeklinde ayrı ayrı yer vermiştir ${ }^{83}$.

Yukarıda yer verdiğimiz kurallara rağmen uluslararası hukukta uzun dönemli sözleşmeleri müzakere etme yükümlülügüne ilişkin ortak bir görüşün bulunduğu söylenemez.

\section{§ 4. HAKEMLERIN SÖZLEŞMELERİ UYARLAMA VE TAMAMLAMA YETKİLERİ}

Sözleşmeye bağl1lık (pacta sunt servanda) ilkesinin, hakemlerin taraflarca yetkilendirilmeleri halinde sözleşmeleri değişen şartlara uyarlamasını engelleyemeyeceği kabul edilmektedir. Yetkilendirme tahkim anlaşması içerisinde yer alabilir. Örneğin, tarafların tahkim anlaşmasına koydukları, hakemlerin "sözleşme değişiklikleri de dâhil olmak üzere

83 Metinler için bkz https://iccwbo.org/content/uploads/sites/3/2020/03/icc-forcemajeurehardship-clauses-march2020.pdf, (Edinim Tarihi: 03.09.2020). 
sözleşmeden kaynaklanan tüm uyuşmazlıklar" ${ }^{84}$ için yetkili olduğuna ilişkin bir ifade hakemlere böyle bir yetki verildiğini göstermektedir. Bununla birlikte, sözleşmede açıkça bir yetkilendirme olmasa dahi, sözleşmenin yorumu kapsamında, sözleşmenin amacı ve önemine bakılarak hakemlerin bu konuda yetkilerinin olup olmadığ 1 tespit edilebilir ${ }^{85}$. Uzun dönemli sözleşmelerde, MTO Tahkimine atıfta bulunulması ve birçok sözleşme hükmünde değişikliğin öngörülmesinin hakemlere bu yetkiyi verdiği kabul edilmektedir ${ }^{86}$.

Sözleşmede yer alan aşırı ifa güçlügüne, uyarlamaya veya yeniden müzakereye ilişkin hükümlerin tahkim anlaşmasına atıfta bulunması halinde hakemlerin yetkisi bulunmaktadır. Uygulamada kolaylık açısından hakemlere verilen yetkilendirmenin kapsamı, sınırları ve değişikliği tetikleyen olayların açık ve kesin bir şekilde belirtilmesi gerekmektedir.

Hakemlerin sözleşmeyi tamamlama ve uyarlama konularında taraflarca yetkilendirilmemeleri halinde, genellikle tahkim yeri hukuku şeklinde tezahür eden tahkim usulüne uygulanacak hukuka (lex arbitri) ve esasa uygulanacak hukuka (lex causae) göre hakemlerin uyarlama yetkilerinin olup olmadığ 1 belirlenmektedir. Lex arbitri hakemlerin usuli olarak sözleşme değişikliğine, boşluk doldurmaya yetkili olup olmadıklarını belirlemektedir. Lex arbitri hakemlerin sözleşmeyi değiştirmesine/uyarlamasına izin vermiyor ${ }^{87}$, ancak sözleşmenin esasına uygulanacak hukuk buna izin veriyorsa, uyarlama sözleşmesel bir değişiklik olmakla beraber, Yabancı Hakem Kararlarının Tanınması ve İcrası Hakkındaki 10 Haziran 1958 tarihli New York Sözleşmesine ${ }^{88}$ göre hakem kararının tenfizi reddedilebiliir ${ }^{89}$. Dolayısıyla

84 İngilizce olarak genelde şöyle bir ifadeye rastlanmaktadır: "All disputes arising out of the contract including a change of contract itself". Ayrica bkz. BERGER, K.P.: "Power of Arbitrators to Fill Gaps and Revise Contracts to Make Sense", Arbiration International 2001, Vol. 17, No. 1, s. 3.

85 BERGER, Power of Arbitrators, s. 4.

865754 sayılı MTO hakem kararına konu olan uyuşmazlıkta, tarafların uzun süreli sözleşme fiyatının revize edilmesi hakkında anlaşamaması nedeniyle hakemler tahkim kaydını geniş yorumlayarak kendilerini yetkili görmüşlerdir: Peter, s. 254; BERGER, Power of Arbitrators, s. 7.

87 Bkz. arka sayfa.

88 Sözleşmenin İngilizce metnine http://www.newyorkconvention.org/english, (Edinim Tarihi: 03.09.2020) adresinden ulaşılabilir. Türkçe metin için bkz. RG. 25.09.1991-21002. Sözleşmenin uygulanmasına yönelik hakimler için el kitabı için bkz. https://www.arbitration-icca.org/media/3/14344084296340/icca_guide_turkish_final.pdf , (Edinim Tarihi: 03.09.2020)

89 VAN den BERG, A.: "The New York Arbitration Convention of 1958", T.M.C. Asser Institute-the Hague, s. 46. Bkz. http://newyorkconvention1958.org/index.php?lvl=notice- 
esasa uygulanacak hukukun verdiği sözleşme değişikliğine izin vermiş olması aslında faydasız olacaktır. Esasa uygulanacak hukuk, hakemlerin uyarlama işleminde nasıl bir yol izlenmesi gerektiğini ve koşullarını belirlemektedir. Örneğin İsviçre hukukunun esasa uygulanacak hukuk olması halinde hakemlerce İsviçre doktrini tarafindan geliştirilen clausula rebus sic stantibus ilkesini ve yargısal kararlarla geliştirilen İsviçre Medeni Kanunu m. 2 uygulanacaktır ${ }^{90}$. Bununla birlikte, bazı ülkelerde tahkim kanunları hakemlere sözleşme değiştirme ve boşluk doldurma yetkisi vermektedir ${ }^{91}$.

Hakemlerin ilgili tahkim kanunlarında boşluk doldurma ile yetkilendirilmemiş olması halinde, söz konusu uyuşmazlığ 1 görmeye yetkili mahkemelerin böyle bir yetkisinin olup olmadığına bakılması gerektiği; bu durumda eş zamanlı yetkilendirmenin (synchronized competences) uygulanması önerilmektedir. Buna göre, mahkemelere böyle bir yetki verilmiş olması, söz konusu yargı alanındaki tahkim kanunun kapsamında hareket eden hakemlere de bu yetkinin verildiği anlamına gelmektedir ${ }^{92}$. Ancak millî usul kanununda mahkemelerin böyle bir yetkisi bulunmuyorsa, ilgili yargilama yerindeki maddî hukuk kurallarına bakılarak mahkemelerin ve dolayısıyla hakemlerin boşluk doldurma yetkilerinin olup olmadığ 1 belirlenebilir. Örneğin, Alman Medeni Kanunu mahkemelerin ve hakemlerin sözleşmeyi değiştirme ve boşluk doldurmalarına ilişkin hüküm içermemektedir. Ancak BGB, mahkemelere tarafların anlaşamamaları halinde sözleşmeyi değiştirme yetkisi vermektedir. Dolayısıyla tahkim yerindeki tahkim kanunu, usûl kanunu ve maddî kanunun yetki vermediği hallerde uyuşmazlığın esasına uygulanacak hukuka bakmak gerekecektir ${ }^{93}$.

\footnotetext{
_display\&id=2598\&opac_view=6, (Edinim Tarihi: 03.09.2020); BERGER, Power of Arbitrators, s. 9; FRICK, s. 193.

90 FRICK, s. 193.

91 Örneğin, 2015 Hollanda Tahkim Kanunu, m. 1020 (4) c'de böyle bir hüküm yer almaktadir: "Parties may also agree to submit the following matters to arbitration ..(c) the filling of gaps in or modification of the legal relationship between the parties referred to in paragraph (1)".

92 BERGER, Power of Arbitrators, s. 10; PETER, s. 256-257. BERNARDINI, P.: "Stabilization and Adaptation in Oil and Gas Investments", The Journal of World Energy Law \& Business 2008, Vol. 1, No.1, s. 98-112. Bkz. https://doi.org/10.1093/jwelb/jwn001, , (Edinim Tarihi: 03.09.2020). Aksi yönde görüş için bkz FRICK, s. 193-194. FRICK, sözleşmenin uyarlanması konusunda esasa uygulanacak hukuk ile usule uygulanacak hukukun karıştırıldığını ve hakemlere uyarlama için sınırsız bir yetkinin verilmesinin tehlikeli olduğunu, sınırların ve koşulların esasa uygulanacak hukuk tarafından belirlendiğini ifade etmektedir.

93 BERGER, Power of Arbitrators, s. 9-10.
} 
Uyuşmazlığın esasına uygulanacak hukuk, sözleşmede ayrıntılı hüküm olmadığı zaman sözleşmedeki değişikliği içeren hükmün geçerliliği, taraflarca sözleşme değişikliği için belirlenen şartlar, sözleşmenin yorumlanmasına ilişkin ilkeler ve değişiklik için hakemlerin izlemesi gereken yolları belirleyecektir ${ }^{94}$. Sözleşmenin esasına uygulanacak hukuk, hakemlere bu konuda kararlar verirken esneklik sağlamış olabilir. İlk olarak değişen koşullar 1şığında, bir sözleşmenin açıkça değiştirilmesi yetkisini verebilir. İkinci olarak, uyuşmazlıkta hakemlerin uygulanacak hukuku belirli hallerde katı bir şekilde uygulamalarının önüne geçerek kararın iptalini sadece kamu düzeninin (ordre public) ihlali ile sınırlandırabilir. Üçüncü olarak, yine kamu düzeninin sınırları içinde uygulanacak hukukun katı bir şekilde uygulanmaksızın kararın genel adalet ve hakkaniyet kurallarına göre verilmesine izin verebilir ${ }^{95}$.

Sonuç olarak, hakemlerin sözleşmeyi uyarlama yetkilerinin olup olmadığı uyuşmazlığın tahkime elverişliliği (arbitrability) ve tahkim anlaşmasının kapsamı ilgili bir husus iken, uyarlamanın koşulları ve izlenecek yol esasa uygulanacak hukuk sorunudur ${ }^{96}$.

\section{Taraflarca Hukuk Seçiminin Yapılması}

Tahkim yargısında, hakemler taraflarca seçilen hukuka saygı göstermektedir. Bununla birlikte, doğrudan uygulanan ya da müdahaleci kurallar olarak bilinen kurallar sözleşme üzerinde veya tarafların karşılıklı hak ve yükümlülükleri üzerinde etkili oldukları takdirde, bu kuralların kapsamına giren konularda taraflarca seçilen hukukun uygulanmaması söz konusu olabilir $^{97}$.

Neredeyse tüm doğal gaz alım ve satım sözleşmeleri doğrudan müzakere etme hükmü içermese bile mücbir sebep hükümleri içermektedir. Geçmişte mücbir sebep ile ilgili hükümler standart metinler şeklindeyken, günümüzde üzerinde tartışılan ayrıntılı hükümler haline gelmiştir. Bu durum mücbir sebep hükümlerinin kapsamının açı bir şekilde tanımlanmasını, mücbir sebep

94 BERGER, Power of Arbitrators, s. 10.

95 HORN, N.: "Procedures of Contract Adaptation and Renegotiation in International Commerce", Adaptation and Renegotiation of Contracts in International Trade and Finance, (ed. HORN), Antwerp, Boston, London, Frankfurt, 1985, s. 179.

96 FRICK, s.197.

97 SILBERMAN, L./FERRARI, F.: "Getting to the Law Applicable to the Merits in International Arbitration and Consequences of Getting It Wrong", Conflict of Laws in International Arbitration, (Eds. Ferrari, F/ Kröll, S.), European Law Publishers, 2011, s. 263. 
savunmasının yasal gerekliliklerinin açıkça ortaya konmasını ve sözleşmenin esasına uygulanacak hukuka göre yapılacak savunmalarla ilişkilerini içermektedir. $\mathrm{Bu}$ bağlamda sözleşmedeki mücbir sebep hükmünün, uygulanacak hukukun mücbir sebep ile ilgili hükümlerin yerine geçerek kendi kendine yeterli olup olmadığı veya uygulanacak hukuktaki hükümleri tamamlamaya yönelik olup olmadığı sorusu ile karşılaşılmaktadır. İlk halde, hakemler sözleşme hükmünün yorumunu uygulanacak hukuktan ayrı yapma eğilimindeyken, ikinci halde sözleşme hükmünün uygulanacak hukuk kapsamında yorumlanması gündeme gelmektedir ${ }^{98}$.

Doktrinde, uygulanacak hukukun tespit edilmesine her zaman gerek olmadığı, taraflarca hukuk seçiminin yapılmadığı hallerde uyuşmazlığıın sözleşme hükümlerinin uygulanması ile çözülebileceği de ileri sürülmektedir. ${ }^{99}$.

UNCITRAL Model Kanununun ${ }^{100}$ 28. maddesi uyarınca hakem heyeti her durumda sözleşme hükümlerine göre karar verecek ve işleme uygulanacak ticarî teamülleri dikkate alacaktır. Bu durum, hakemlerin dostane aracı olarak hareket ettikleri hallerde de geçerlidir. MTO Tahkim Kurallar1 ${ }^{101} \mathrm{~m} .21$ ve UNCITRAL Tahkim Kurallar ${ }^{102} \mathrm{~m} .35$ 'te de aynı yaklaşım benimsenmiştir.

\section{A. Millî Hukuk Seçimi}

Taraflarca seçilen hukuk bir devletin yürürlükte olan hukuku ise bu durumda da sözleşmenin değişen şartlara göre revizyonunu sağlayan bir mücbir sebep maddesi ile uygulanacak hukuk arasındaki ilişkiyi çözmek hakemler açısından zorlu bir görev olarak ortaya çıkmaktadır.

MTO'nun 4462 numaralı hakem heyetinin karar ${ }^{103}$ Libya Devlet Şirketi National Oil Corporation ile Amerikalı Libyan Sun Oil Company arasındaki ürün paylaşım sözleşmesinden kaynaklanan uyuşmazlığa ilişkindir. Bu dava, sözleşmede yer alan mücbir sebep hükmü ile Libya hukuku (esasa

98 BERGER, K.P:" Force Majeure Clauses and their Relationship with the Applicable Law, General Principles of Law and Trade Usages", ICC Digital Library.

99 SILBERMAN/FERRARI, s. 264.

$100 \mathrm{https} / / /$ www.uncitral.org/pdf/english/texts/arbitration/ml-arb/06-54671_Ebook.pdf, (Edinim Tarihi: 04.09.2020)

101 https://iccwbo.org/dispute-resolution-services/arbitration/rules-ofarbitration/\#article_21,(Edinim Tarihi: 04.09.2020)

$102 \mathrm{https} / /$ www.uncitral.org/pdf/english/texts/arbitration/arb-rules-revised/arb-rules-revised2010-e.pdf, (Edinim Tarihi: 04.09.2020)

103 BERGER, Force Majeure Clauses; ICC Award No. 4462 of 1985. National Oil Corporation v Libyan Sun Oil Company, International Legal Materials 1990, s. 565 vd. 
uygulanacak hukuk) arasındaki ilişkinin taraflarca net olarak belirtilmemesi nedeniyle hakemlerin karşılaştıkları zorlukları ortaya koyan bir örnek olarak dikkati çekmektedir. Uyuşmazlık, ABD'nin 1981 yılında yaptı̆̆ 1 düzenleme ile kendi vatandaşlarının pasaportlarının Libya'da geçerli olmadığına karar vermesi ve 1982 yılında ise Libya'ya ihracat kısitlamas1 yapmas1 nedeniyle ortaya çıkmıştır. Libyan Sun Oil Company mücbir sebebe dayanarak yükümlülügünü ifa etmesinin imkânsız olduğunu bildirmiştir. National Oil Corporation'un bu durumu mücbir sebep olarak kabul etmemesi üzerine, uyuşmazlık Libyan Sun Oil Company tarafından MTO tahkimine taşınmıştır. Hakem heyeti mücbir sebep iddiasını kabul etmeyerek National Oil Company lehine karar vermiştir. Söz konusu uyuşmazlıkta, sözleşmede mücbir sebebe ilişkin bir hüküm bulunmakla birlikte, hükmün kapsamı Libya hukukunda yer alan mücbir sebep şartlarından daha dar olarak belirlenmiştir. Tarafların seçtiği, Libya hukukunda öngörülemezlik (unforeseeability), kaçınılmaz olma (unavoidability), kontrolün ötesinde gerçekleşme (uncontrollability) ve ifanın imkânsız olması (impossible) aranmaktayken, taraflar arasındaki sözleşmede öngörülmeyen (unforeseen) olay, ifanın mücbir sebep nedeniyle gerçekleştirilememesi (the performance shall be excused to the extent attributable to force majeure) ve olaydan etkilenme (affected) şartları yer almaktadır. Taraflar, kendi iradelerinin net olarak ortaya konması için, hakemlerin sözleşmede yer alan mücbir sebep hükümlerine bakması ve sözleşmede yer alan ifadeler ile Libya hukuku ilişkisini değerlendirilmesi gerektiği konusunda mutabık kalmıştır. Hakem heyeti, sözleşmede kullanılan etkilenme (affected) ifadesinin tek başına tarafların Libya hukuku kapsamında imkânsızlık şartından feragat ettiklerine ilişkin kesinlik taşımadığını, ifanın daha zor ve pahalı olmasının mücbir sebep için yeterli olmayacağını, mücbir sebep için ifanın objektif, kesin ve imkânsız olması gerektiğini, açık bir ifade olmadığı sürece sözleşmenin mücbir sebebe ilişkin hükmünün Libya hukukunun uygulanmasını engellemediği sonucuna varmıştır. Hakem heyeti $\mathrm{ABD}$ tarafindan yapılan düzenlemelere rağmen ifanın yapılabileceğine, nitekim diğer Amerikan şirketlerinin bu düzenlemelere rağmen farklı yollarla edimlerini ifa ettikleri örneklere gönderme yaparak mücbir sebep iddiasını reddetmiştir.

5864 numaralı MTO hakem kararında ${ }^{104}$ ise hakem heyeti aksine bir karar vermiştir. Ancak söz konusu tahkimde sözleşmede yer alan mücbir sebep hükmü Libya hukukunda yer alan imkânsızlık şarıtını da içermekteydi. ${ }^{105}$

104 ICC Award No. 5864, Clunet 1997, https://www.trans-lex.org/205864, (Erişim Tarihi: 04.09.2020).

105 Bkz. BERGER, Force Majeure Clauses. 
MTO'nun 19299 numaralı hakem kararında ${ }^{106}$ ise hakem heyeti üretim paylaşım sözleşmesinde yer alan mücbir sebep hükmünün açık olduğunu, tarafların belirli ve kesin ifadeler kullanarak Yemen hukukunda yer alan mücbir sebep şartlarının bazılarına sözleşmelerinde yer verdiklerini, ancak imkânsızlık şartına yer vermediklerini ve böylece tarafların sözleşmelerinde kendi kendine yeten (self-sufficient) bir mücbir sebep hükmü üzerinde mutabık kaldıklarına karar vermiştir. Hakem heyeti, ayrıca, sözleşmenin 18.2 maddesine göre sözleşmenin taraflar arasındaki hak ve borçlar için tek kaynak olduğuna, tarafların da hak ve borçlarının sözleşmeye göre belirleneceğine karar verdiklerini; tarafların Yemen hukukunun uygulanmasını istediklerini sözleşme hükümlerinde açıkça ortaya koyduklarını, ancak mücbir sebep hükmünde Yemen hukukuna atıfta bulunulmadığını da belirtmiştir ${ }^{107}$.

Tarafların millî bir hukuku seçtiği hallerde, hakemlerin lex mercatoriayı tamamlayıcı kurallar olarak uygulayabilecekleri de kabul edilmektedir. $\mathrm{Bu}$ durumda lex mercatoria ikincil kaynak niteliğindedir ${ }^{108}$. MTO'nun 8873 numaralı hakem karar ${ }^{109}$, hakemlerin tarafların millî hukuku seçme konusundaki açık iradelerine rağmen, hakemlerin ulus ötesi kuralları uyguladıkları bir karar olması açısından önemlidir. Uyuşmazlıkta davalı, İspanyol hukukunun ticarî örf adet kurallarının iç hukukun sessiz kaldığ 1 konularda tamamlayıcı bir işlev görmesine izin verdiğini kabul etmiştir. Davac1, sözleşme ve ticarî örf adet hükümlerinin ana referans noktası olarak ele alınması gerektiğini ileri sürmüştür. Hakem heyeti davacının görüşünü kabul etmiştir. Hakem heyeti, ticarî örf adetlerin ne ölçüde geçerli olduğunu ve uygulanmasını belirlemek için ulusal hukukun katı kurallarına bağlı olmadığını belirterek, özellikle Cenevre Sözleşmesinin ${ }^{110}$ VII. maddesinin ${ }^{111}$ konuyla ilgil i ulusal kurallar yerine uluslararası düzeyde bir ilke oluşturduğunu belirtmiştir. Bu ilke, hakemlerin, uygulamaları gereken ticarî

${ }^{106}$ Karar için bkz. https://www.italaw.com/cases/4209, (Erişim Tarihi: 04.09.2020).

107 Bkz. BERGER, Force Majeure Clauses.

${ }^{108}$ ICC Award No. 1472. Ayrica bkz. CROFF, C.: The Applicable Law in an International Commercial Arbitration: Is It Still a Conflict of Laws Problem, Heinonline International Law 1982, Vol. 16, No. 4, s. 636.

109 https://library.iccwbo.org/dr-awards.htm, (Erişim Tarihi: 04.09.2020)

110 European Convention on International Commercial Arbitration. Sözleşmenin İngilizce metin için bkz. https://treaties.un.org/doc/Treaties/1964/01/19640107\%200201\%20AM/Ch_XXII_02p.pdf, (Erişim Tarihi: 04.09.2020).

111 Söz konusu hüküm uyarınca "Taraflar hakemlerin ihtilâfin esasına tatbik edecekleri hukuku tayin etmekte serbesttirler. Eğer taraflar tatbik edilecek hukuku kararlaştırmamışlar ise hakemler ihtilâfin nev'ine göre münasip görecekleri kanunlar ihtilâfi kaidesinin tayin ettiği kanunu tatbik edeceklerdir. Her iki halde hakemler mukavele hükümlerini ve ticarî adetleri nazara alacaklardır". 
örf adet kurallarını belirlemek için geniş takdir yetkisine sahip olduklarını kabul etmektedir. Hakem heyeti devamında, Uluslararası Ticari Tahkime ilişkin 1961 Avrupa Sözleşmesine göre ulus ötesi ilkelerin uygulanacak millî hukukun doğrudan uygulanan kurallarına aykırı olmadığı sürece uygulanacağını belirtmiştir. Bu kapsamda hakemlerin takdir yetkileri oldukça geniş tanımlanmıştır. Benzer bir yaklaşım MTO'nun 7518 numaralı hakem kararında $^{112}$ da kabul edilmiştir. Taraflar, uyuşmazlıkları için tek hukuk olarak Portekiz hukukunu belirlemiş olsalar da, hakemler, ticarî örf adet kurallarına ve özellikle sözleşmeye bağl1lık (pacta sunt servanda) ilkesine, doğrudan uygulanan kurallarına aykırı olmadığı sürece Portekiz hukukunun üzerinde uygulama alanı vermiştir. $\mathrm{Bu}$ tarz kararlar iç hukukun uygulanmasının söz konusu olduğu uyuşmazlıklarda lex mercatorianın ilave veya hatta düzeltici kullanım sınırlarını aştı̆̆ ve kararlarda ulus ötesi kuralların birincil zemine oturtulduğu kurallar olarak önemlidir ${ }^{113}$. Söz konusu hakem kararı, aynı zamanda sözleşmede yer alan haklar ve yükümlülüklere, dış kuralların kabul edilebilir müdahalesinin derecesini belirlemek için diğer MTO hakemleri tarafından kullanılan genel bir kılavuz oluşturmuştur. Yargılama yetkisini tarafların iradelerinden alan uluslararası hakemler, tarafların uygulanacak hukuktan ve sözleşmenin mücbir sebep ile ilgili hükmünde yer almayan ancak ticarî örf adet veya hukukun genel ilkelerinden elde edilen meşru beklentilerini korumalıdır. Dolayısıyla taraflar hakemlerin sonraki uyuşmazlıklarda da sözleşmede yer alan mücbir sebep hükmü ile uygulanacak hukuk arasındaki ilişkiyi belirlemede dikkatli olacaklarına güvenirler ${ }^{114}$.

\section{B. Tarafların Millî Olmayan Hukuk Kurallarını Uygulanacak Hukuk Olarak Seçmesi}

Taraflar millî hukuk yerine, uluslararası hukuka, uluslararası örf ve âdet kurallarına, ulus-ötesi kurallara ya da lex mercatoriaya atıfta bulunarak millî olmayan bir hukuk seçimi yapabilirler. Bu durumun mahkeme uygulamasında teknik anlamda hukuk seçimi olup olmadığı tartışmalı iken, tahkim yargılamasında daha esnek bir yaklaşım söz konusudur.

Tarafların millî hukuk dışında 'anasyonel' kurallar olarak adlandırılan lex mercatoriayı seçmeleri halinde hakemlerin bu kuralları uygulamasının temel dayanağının ne olduğu hususunun açıklığa kavuşturulması gerekir. Bu

112 ICC Award No. 7518 (1994), Italian party v. Portuguese party, 125 J.D.I. 1034 (1998).

113 JEMIELNIAK, J.: Legal Interpretation in International Commercial Arbitration, Routledge, London, New York 2016, s. 167-168.

114 BERGER, Force Majure Clauses. 
bağlamda, millî hukuk düzenlemelerinde ve milletlerarası belgelerde bir devletin hukukundan bahsedilmeyip hukuk kuralları ibaresine yer verilmesi, tarafların hukuk seçiminde mutlaka bir devletin hukukunu seçmek zorunda olmadığının kanıtını oluşturduğu savunulmaktadır ${ }^{115}$. Örneğin, Türk Milletlerarası Tahkim Kanununda (m.12/c), Fransız Tahkim Kanununda (m. 1511), İsviçre Milletlerarası Özel Hukuk Kanununda (m. 187) ve UNCITRAL Model Kanununda (m. 28/1) hakemlerin uyuşmazlığı tarafların uyuşmazlığın esasına uygulanmak üzere seçtikleri hukuk kurallarına göre çözeceği düzenlenmektedir.

Hakemlerin, tarafların ulusal olmayan bir hukuku seçmelerine saygı gösterip göstermeyecekleri konusunda diğer bir yaklaşım ise, kanunlar ihtilâfı kurallarının sadece bir devletin yürürlükte olan millî hukukunun uygulanmasına izin verdiği, lex mercatorianın uyuşmazlığın tüm sorunlarını çözmeye yetecek kadar gelişmiş bir sistem olmadığı, bu nedenle hakemlerin taraflarca yapılan seçimi dikkate alacakları, ancak lex mercatoria içerisindeki boşlukların yine millî hukuk ile doldurulacağ kabul edilmektedir $^{116}$.

\section{UNIDROIT Kurallarının Seçimi}

Taraflarca herhangi bir hukukun seçilmediği veya hukukun genel ilkelerine atıf yapıldığ 1 hallerde UNIDROIT Kuralları doğrudan uygulama alanı bulur mu? UNIDROIT Kuralları sözleşme hukukunun çoğunlukla kabul görmüş ilkelerini yansıtmayı amaçladığından söz konusu ilkeler lex mercatorianın formüle edilmesi olarak karşımıza çıkmaktadır. Ancak burada tarafların UNIDROIT Kurallarının düzenleme yapmadığı zamanaşımı, sözleşme kaynaklı cezalar, devir gibi konularda başka bir hukuku seçip seçemeyecekleri sorusu akla gelmektedir. Bu durumda sözleşme görüşmeleri aşamasında tarafların bu hususu dikkate almaları önem arz etmektedir ${ }^{117}$. UNIDROIT Kurallarının doğrudan uygulama alanı bulmasına ilişkin ilk bakışta olumlu cevap verilebilir gibi gözükse de somut olayın özellikleri dikkate alınarak prensiplerin geniş bir şekilde analiz edilmesi gerekmektedir ${ }^{118}$.

115 GAILLARD, E./ SAVAGE, J..: Fouchard Gaillard Goldman on International Commercial Arbitration, Part II, Kluwer Law International, the Hague 1999, s. 809.

116 CROFF, s. 623

117 BLESSING, M.:"Regulations in Arbitration Rules on Choice of Law” International Council for Commercial Arbitration, Planning Efficient Arbitration Proceedings, Working Group II:The Law Applicable in International Arbitration, (General Editor. Albert Van Den Berg), s. 395

118 BLESSING, s. 395. 


\section{Hukuk Seçiminin Olmadığı Hallerde Hakemlerce Uygulanacak Hukuk Tespiti}

Taraflarca uygulanacak hukukun seçilmediği hallerde, hakemler kanunlar ihtilâfı kurallarına başvurarak veya kanunlar ihtilâfı kurallarına başvurmaksızın uygulanacak hukuku belirleyebilir. Hakemlerin lex arbitrinin kanunlar ihtilâfi kurallarına bakmaları gerektiği görüşü hakemlik kurumunun millî bir hukuka bağlı olması gerektiğinden hareket etmektedir.

Hakemlerin, herhangi bir kanunlar ihtilâfı kuralına başvurmaksızın ve millî bir hukuku uygulanacak hukuk olarak tespit etmeksizin millî olmayan hukuku, örneğin lex mercatoriayı uygulaması hakemliğin millî olmayan karakterini (denationalized) esas almaktadir ${ }^{119}$.

Her iki durumda da uygulanacak hukukun tespiti açısından hakemlere tanınan takdir yetkisi önem arz etmektedir. Hakemlerin lex mercatoriayı uygulama serbestisine sahip olmaları takdir yetkisinin en geniş olduğu haldir $^{120}$.

Uluslararası tahkim uygulamasında, hakemlerin uygulanacak hukuk sıfatıyla lex mercatoriayı esas aldığ 1 pek çok uyuşmazlık vardır. Bu uyuşmazlıklarda, tarafların hukuk seçimi yapmaması veya her iki tarafın uygulanacak hukuk olarak kendi hukukunun uygulanmasında israr etmiş olmaları nedeniyle hakemler uyuşmazlığın yapısını dikkate alarak lex mercatoriayı uygulamıştır ${ }^{121}$.

Tâbi oldukları tahkim kurallarının izin vermesi halinde millî hukuk yerine 'anasyonel' kurallara göre uyuşmazlığ çözmeleri mümkün kılınmış olsa $\mathrm{da}^{122}$, hakemlerin uygulanacak hukuku tespit ederken, tarafların meşru beklentilerini dikkate almaları gerekmektedir. Millî hukuklar yerine ulus ötesi ticaret hukuku olarak nitelendirilen 'anasyonel' kuralların uygulanması hakem kararlarının iptaline veya tenfizinin reddedilmesine olabilir.

119 Aşamalar konusunda ayrıntılı bilgi için bkz. CROFF, s. 623- 638. Türk hukukunda Milletlerarası Tahkim Kanunu m. 12'de tarafların hukuk seçimi yapmamaları halinde hakem veya hakem heyeti, uyuşmazlıkla en yakın bağlantı içinde olan devletin maddi hukuk kurallarına göre karar verir.

${ }^{120}$ Bununla birlikte, doktrinde lex mercatorianın uygulanmasına şüphe ile yaklaşılmakta ve dostane aracı durumunda lex mercatoria'nın uygulanması savunulmaktadır. İngiliz hukuku lex mercatoriayı hukuk olarak değil dostane aracı uygulaması olarak görmektedir: ÖZEL, S.: Milletlerarası Ticari Tahkimde Kanunlar İhtilafi Meseleleri, Legal, İstanbul 2008, s.152.

121 MTO Tahkim No. 1859; CROFF, s. 637.

122 ÖZEL, s. 143; ŞANLI. C.: Milletlerarası Ticari Tahkimde Esasa Uygulanacak Hukuk, Ankara 1986, s. 314. 
Hukukun genel ilkelerini uygulayan hakem, bu kuralları saptarken daha esnek bir değerlendirme yetkisine sahiptir. Bu kurallar uluslararası hukuktaki boşlukları doldurma işlevine sahiptir. Böylece uluslararası hukukta kural yokluğu nedeniyle bir davanın reddinin (non liquet) önlenmesi amaçlanmaktadır. Ancak hukukun genel ilkelerine tanınan bu işlev hakkaniyete uygun çözüm yönteminin aksine uygulanacak hukukun hâkim tarafından yaratılacağı anlamına gelmemektedir ${ }^{123}$.

\section{Hakemlerin Dostane Aracı Olarak veya Hak ve Nesafete Göre Karar Vermeleri}

Taraflarca aksi kararlaştırılmadığ sürece hakemler önlerine gelen uyuşmazlığ1 sözleşme, ticarî örf âdet ve uygulanacak hukuk kapsamında çözmelidir. Bu durumun tek istisnası tarafların hakemlere âdil ve hakkaniyete dayanan bir çözüm bulma konusundaki verdikleri yetkidir. Bu tarz esnek ve hukukî olmayan standartlar, genellikle dostane aracılık (amiable composition), hakemlerin bu şekilde karar vermeleri ise hakkaniyet ve nesafete (ex aequo et bono) göre karar verme olarak adlandırılmaktadır ${ }^{124}$. Bu tarz bir yöntem için gerekli şart tarafların mutabakatıdır ${ }^{125}$.

Hakemler dostane aracı veya hakkaniyet ve nesafete göre karar verirken, katı hukuk kurallarından veya yorumlarından bağımsız hareket ederek, hakkaniyeti ölçü alarak uyuşmazlığı çözmektedir ${ }^{126}$. Bu durumda, hakemler uygulanacak hukuk kurallarını uygulamaktadır; ancak bu hukukun adil olmayan sonuçlarından sapma yetkisine sahiptir. Hakemlerin sadece millî hukuku değil, milletlerarası hukukun genel prensiplerini veya 'anasyonel'

123 PAZARCI, H.: Uluslararası Hukuk, Gözden Geçirilmiş 18. Bası, Turhan Kitabevi, Ankara 2019, s. 120.

${ }^{124}$ LEW, J./ MISTELIS, L./ KRÖLL, S.: Comparative International Commercial Arbitration, Kluwer Law International, The Hague 1994, s. 470 Amiable composition ile ex aequo et bono arasında bir ayrım olduğu amiable composition halinde hakemlerin zorunlu uygulanan (mandatory) kurallar dahil olmak üzere hukuki kurallardan ayrılabileceği ancak ex aequo et bono halinde ise hakemlerin hukukun etkilerini hafifletmek için hukuka uygun karar vermeleri gerektiği belirtilmektedir. Bununla birlikte UNCITRAL Model Kanun ve MTO Tahkim Kurallarında iki kavram farklılık gözetmeksizin aynı anlamda kullanılmıştır. Birçok yazar da iki kavramı birbirinin yerine geçecek şekilde kullanmıştır.

125 ŞANLI, böyle bir durumda hakem kararlarının icrasının iç hukuka uygun ancak taraf anlaşmaları dikkate alınmaksızın verilen kararlara göre şansının daha yüksek olduğunu savunmaktadır. SANLI, s. 170.

126 AKINCI, Z.: Milletlerarası Tahkim, 4. B, Vedat Kitapçılık, İstanbul 2016, s. 234. ŞANLI hakemlerin hakkaniyete göre karar vermeye yetkili olduğu durumlarda da kararlarını istinat ettikleri hukuk normlarının tüm millî hukuk sistemlerinde mevcut olduğunu ve dolayısıyla kararlarını bir hukuka dayandırdıklarını savunmaktadır: ŞANLI, s. 174. 
kurallarını uygulama yükümlülükleri de ortadan kalkmaktadır. Ancak hakemler uluslararası kamu düzeni (international public policy) kurallarını göz ardı edemezler; aksi halde hakem kararının iptali ya da tenfiz edilmemesi riski söz konusu olabilecektir. Aynı şekilde, hakemlerin tarafların adil yargılanmaya ilişkin haklarına da uyma yükümlülükleri bulunmaktadır ${ }^{127}$.

Hakemlerin hakkaniyet ve nesafete göre karar vermekle yetkilendirilmeleri halinde, sözleşme hükümlerini hakkaniyet ve adalet adına bertaraf etme yetkisine zımnî olarak sahip olabilecekleri ileri sürülebilse ${ }^{128}$ dahi, taraflarca açık yetki verilmedikçe hakemlerin sözleşme hükümlerini değiştirme, yeniden yazma veya bu hükümleri uygulamaktan kaçınmaları mümkün değildir ${ }^{129}$. Dolayısıyla, bir doğal gaz alım ve satım sözleşmesinde yer alan fiyat revizyonu hükmüne dayanılarak talep edilen fiyat değişikliğinin mutabakatla sonuçlanmaması nedeniyle uyuşmazlığın tahkim yoluna götürülmesi halinde, hakemler dostane aracı olarak sözleşmedeki fiyat formülünün yapısını tamamen değiştiremezler; ancak mevcut formüldeki parametreleri değişen şartlara uyarlayabilirler.

Esasa uygulanacak hukuk açısından tarafların hakemlere dostane aracı olarak karar verme yetkisi tanıdığı durumlarda hakemlerin yetkilerinin sınırlarını tespit etmek önemlidir. Hakemler bu durumda belirli bir hukuka bağlı olmaksızın daha esnek karar vermekle yetkilendirilmektedir. Paris Temyiz Mahkemesinde hakem kararının iptaline ilişkin görülmekte olan bir uyuşmazlıkta ${ }^{130}$ taraflar hakemleri dostane aracı olarak yetkilendirdikleri halde hakemlerin belirli bir hukuku uygulamaktan kaçınmalarının istendiği belirtilmiştir. Somut olayda hakemler kararlarını İsviçre hukukuna dayandırmamakla birlikte daha âdil bir karar verebilmek için İsviçre hukukunun bazı kurallarına atıfta bulunmuşlardır. Mahkeme kararın yetki aşımı nedeniyle iptalini reddetmiştir. Ancak, taraflarca hakemlerin belirli bir hukuk uyarınca karar vermelerini kararlaştırmış olmalarına rağmen hakemlerce bu hukuk dikkate alınmadan dostane aracı olarak hakkaniyet ve nesafet uyarınca karar verilmiş olması kısmî yetki aşımının daha kolay tespit edildiği bir durumdur ${ }^{131}$.

127 GAILLARD/SAVAGE, s. 841.

28 ÖZEL, s. 161

129 ÖZEL, s. 161; CHUCKWUMERIJE, O.: Choice of Law in International Commercial Arbitration, Greenwood Publishing Group, London 1994, s. 120; LEW/MISTELIS/KRÖLL, s. 471; POUDRET, J-F./BESSON,S./BERTI,S./FONTI, A.: Comparative Law of International Arbitration, Ed.2, Sweet \& Maxwell Ltd, London 2007, s. 624.

130 Soubaigne v. Limmareds Skogar

131 BAYATA CANYAŞ, A.: UNCITRAL Model Kanunu Temelinde Uluslararası Ticari Hakem Kararlarına Karșı Başvuru Yolu, Adalet Yayınları, Ankara 2016, s. 182-183. 


\section{SONUÇ}

Birçok hukukçu tarafından yeniden müzakere hükümlerinin, sözleşmede istikrarı tehlikeye soktuğu gerekçesiyle gerekli olmadığı savunulmaktadır. Tamamen hukuki açıdan bakıldığında yeniden müzakereye ilişkin hükümler sözleşme değişikliğini gerektirdiği için bu görüş doğrudur. Yeniden müzakere hükümlerinin bulunmaması halinde sözleşme değişikliğinin hukuki dayanağı, sözleşmenin esasına uygulanacak hukuktur. Birçok hukuk sistemi sözleşme değişikliğine ya hiç izin vermemekte veya sıkı kurallara tâbi tutmaktadır. Esnek olmayan bu sonuç ise taraflar için sözleşmede olumsuzluklara neden olmaktadır. Sözleşmelerin yeniden müzakere edilmesinin temelinde politik ve ekonomik nedenler yatmakta olup, bu husus esas itibariyle tarafların müzakere etme gücünü yansıtmaktadır ${ }^{132}$.

Sözleşmeden kaynaklanan yükümlülüklerin ifa edilmemesi için meşru gerekçe sağlayan değişen şartların ve olayların genel bir tanımına veya ayrıntılı bir listesine sözleşmede yer vermek bazı tartışmaların ortaya çıkmasına engel olmamaktadır. Genel bir tanım yapmak liste halinde olayları saymaktan daha az kesinlik sağlasa da, tarafların sözleşmenin yapılması aşamasında öngöremedikleri olayları kapsama avantajı da bulunmaktadır. Meşru gerekçe oluşturacak olayları liste olarak saymak daha fazla kesinlik sağlamakla birlikte sonradan meydana gelen ve büyük önem taşıdığ kanıtlanan belirli bir olayın dâhil edilmemiş olması riskini içermektedir. Bu nedenle tarafların sözleşmenin özel niteliği ve sözleşmeyle ilişkili riskler konusunda bilgi sahibi olarak karar vermeleri gerekmektedir. Liste halinde olayları kapsayan ve olayların genel bir tanımını içeren hükümlere yer vermek riski en aza indiren bir yol olarak önerilebilir.

Kabul edilen yöntem hangisi olursa olsun uygulanacak hukuk ile birlikte hakemlerin yorumuna ihtiyaç olacaktır ${ }^{133}$.

Sözleşmeler, tarafların hukukçuları vasıtasıyla en iyi şekilde düzenlenmiş olsa dahi gelecekteki gelişmelerin belirsizlikleri, değişen şartların asla tam olarak bütün hatları ile ele alınmasını sağlayamamaktadır. Dolayısıyla aşırı ifa güçlüğü, mücbir sebep ve fiyat revizyonu gibi özel risklere ilişkin açık hususlar ile her zaman karşı karşıya kalınabilecektir. Neticede bu hususlara ilişkin sorunların sözleşme hükümlerine dayanarak yeterli şekilde cevaplanması büyük ölçüde sözleşmenin esasına uygulanacak

132 PETER, s. 240.

133 Böckstiegel, s.166. 
hukuka bağlı olacaktır. Çünkü, sözleşme hükümleri uygulanacak hukuk kapsamında değerlendirilecektir.

Çalışmamızda belirttiğimiz üzere farklı hukuk sistemlerinin benimsediği farklı yaklaşımlar, sözleşme hükümlerinin yorumlanmasında ve uygulanmasında etkili olmaktadır. Dolayısıyla bir sözleşme hükmünün ayrıntıl1-kapsayıcı şekilde düzenlenmesi ve uygulanacak hukukla bağlantısının açık olarak ortaya konması, uygulanacak hukuk kapsamında cevaplanması gereken soruların ortaya çıkma ihtimalini azaltır. Bununla birlikte tarafların sözleşme revizyonuna ilişkin öngörüleri gelecekteki tüm değişiklikleri kapsamayacağı için bazı durumlarda uygulanacak hukuka başvurulması kaçınılmazdır. Uygulanacak hukuktaki boşluklar ve yorumun ise hukukun genel ilkelerini de kapsayan lex mercatoria ile doldurulacağ 1 yönündeki eğilim giderek güçlenmektedir ${ }^{134}$.

134 GREENBERG, S. / KEE, C/ WEERAMANTRY, R.: International Commercial Arbitration: An Asia-Pacific Perspective, Cambridge, 2011, s.135; GAILLARD, E./ BANIFATEMI, Y.: IAI Series on Intarnational Arbitration No 5 Precedents in International Arbitration, 2008, s. 27; MANIRUZZAMAN, A. F. M.: "The Lex Marcatorai and International Contracts: A Challenge for International Commercial Arbitration”, American University International Law Review 1999, Vol.14, No. 3, s. 733. 


\section{KISALTMALAR}

\begin{tabular}{|c|c|}
\hline $\mathrm{ABD}$ & Amerika Birleşik Devletleri \\
\hline Arbt. & Arbitration \\
\hline Art. & Article \\
\hline aşa. & aşağıda \\
\hline B. & Bası \\
\hline Bkz. & bakınız \\
\hline BGB & Bürgerliches Gesetzbuch (Alman Medeni Kanunu) \\
\hline C. & Cilt \\
\hline CISG & $\begin{array}{l}\text { United Nations Convention on Contracts for the International Sale } \\
\text { of Goods (Birleşmiş Milletler Uluslararası Mal Satış Sözleşmeleri } \\
\text { Konvansiyonu) }\end{array}$ \\
\hline çev. & Çeviren \\
\hline dn. & dipnot \\
\hline IAI & International Arbitration Institute \\
\hline ICC & International Chamber of Commerce \\
\hline İÜHFM & İstanbul Üniversitesi Hukuk Fakültesi Mecmuası \\
\hline Ed. & Edited/Editör \\
\hline Int. & International \\
\hline J.D.I.. & Journal du droit international \\
\hline karş. & karşılaştırınız \\
\hline m. & madde \\
\hline No. & Number \\
\hline RG & Resmi Gazete \\
\hline s. & sayfa \\
\hline TBK & 6098 sayılı Türk Borçlar Kanunu \\
\hline UAD & Uluslararası Adalet Divanı \\
\hline UCC & Uniform Commercial Code \\
\hline UN & United Nations (Birleşmiş Milletler) \\
\hline UNCITRAL & $\begin{array}{l}\text { United Nations Commission on International Trade Law (Birleşmiş } \\
\text { Milletler Uluslararası Ticaret Hukuku Komisyonu ) }\end{array}$ \\
\hline UNIDROIT & $\begin{array}{l}\text { International Institute for the Unification of Private Law ( Özel } \\
\text { Hukukun Yeknesaklaştırılması için Uluslararası Enstitü) }\end{array}$ \\
\hline vd. & ve devamı \\
\hline Vol. & Volume \\
\hline yuk. & yukarıda \\
\hline
\end{tabular}




\section{KAYNAKÇA}

AKINCI, Z.: Milletlerarası Tahkim, 4. B, Vedat Kitapçılık, İstanbul 2016

ATAMER, Y.: "Satıcının Sözleşmeye Aykırı Davranışı Ekseninde CISG'ın Ifa Engelleri Sistemine Genel Bakış", Milletlerarası Satım Hukuku, Milletlerarası Mal Satımına İlişkin Sözleşmeler Hakkında Birleşmiş Milletler Antlaşması, (CISG), (Ed. Atamer, Y.), On İki Levha, İstanbul 2008.

ATAMER,Y. :Borçlunun CISG Madde 79 Uyarınca Tazminat Sorumluluğundan Kurtulması Halinde Alacaklının Diğer Taleplerinin Akıbeti Ne Olur? https://dergipark.org.tr/tr/download/article-file/179440.

AYANOĞLU MORALI, A.: "Milletlerarası Mal Satımına İlişkin Sözleşmeler Hakkında Birleşmiş Milletler Antlaşması'nın Öngördüğ̈̈ Sorumluluktan Kurtulma Sistemi", Galatasaray Üniversitesi Hukuk Fakültesi Dergisi 2013/1, Milletlerarası Mal Satımına İlişkin Birleşmiş Milletler Anlaşması'nın (CISG) Türk Borçlar Kanunu Çerçevesinde Değerlendirilmesi Sempozyumu Özel Sayıs1, 289-312.

AYOĞLU, T.: "Milletlerarası Menkul Mal Satımları Hakkında Viyana Konvansiyonu'nda Boşlukların Doldurulması", Galatasaray Üniversitesi Hukuk Fakültesi Dergisi 2013, No.1, Milletlerarası Mal Satımına İlişkin Birleşmiş Milletler Anlaşması'nın (CISG) Türk Borçlar Kanunu Çerçevesinde Değerlendirilmesi Sempozyumu Özel Sayısı, s. 87-110.

BAYATA CANYAŞ, A.: UNCITRAL Model Kanunu Temelinde Uluslararası Ticari Hakem Kararlarına Karşı Başvuru Yolu, Adalet Yayınları, Ankara 2016.

BAYSAL, B.: Sözleşmenin Uyarlanması, On İki Levha, İstanbul 2009.

BERGER, K. P.: "Power of Arbitrators to Fill Gaps and Revise Contracts to Make Sense, Arbitration. International 2001, Vol. 17, No 1,s. 1-17. (Power of Arbitrators)

BERGER, K. P.: "Force Majeure Clauses and their Relationship with the Applicable Law, General Principles of Law and Trade Usages", ICC Digital Library. (Force Majeure Clauses)

BERNARDINI, P.: Stabilization and Adaptation in Oil and Gas Investments, The Journal of World Energy Law \& Business 2008, Vol. 1, No. 1, s. 98-112.

BLESSING, M.:"Regulations in Arbitration Rules on Choice of Law" International Council for Commercial Arbitration, Planning Efficient Arbitration Proceedings, Working Group II:The Law Applicable in International Arbitration, , (General Editor. Albert Van Den Berg), 391-446.

BLYSCHAK, P. M.: "Arbitrating Overseas Oil and Gas Disputes: Breaches of Contract Versus Breaches of Treaty", Journal of International Arbitration 2010, Vol.27, No. 6. s. 579-629. 
BÖCKSTIEGEL, K-H.: "Hardship, Force Majeure and Special Risk Clauses" Adaptation and Renegotiation of Contracts in International Trade and Finace, (Ed. Rorbert Horn), Kluwer Law International, Deventer/Netherlands/Antwerp/Boston/London/Frankfurt, 1995.

CHUCKWUMERIJE, O.: Choice of Law in International Commercial Arbitration, Greenwood Publishing Group, London 1994.

CROFF, C.: "The Applicable Law in an International Commercial Arbitration: Is It Still a Conflict of Laws Problem", Heinonline International Law 1982, Vol. 16, No. 4, s. 613-645

Energy Charter Secretariat, Putting a Price on Energy, International Pricing Mechanism for Oil and Gas, 2007.

EREN, F.: Borçlar Hukuku Genel Hükümler, Yetkin Yayınları, Ankara 2019.

FRICK, J.: Arbitration and Complex International Contracts, Kluwer Law International, Zürih, Hollanda 2001.

FUCCI, F.: "Hardship and Changed Circumstances as Grounds for Adjustment or Non-Performance of Contracts, Practical Considerations in International Infrastructure and Finance" A, American Bar Association Section of International Law, Spring Meeting, April 2006

GAILLARD, E./SAVAGE, J.: Fouchard Gaillard Goldman on International Commercial Arbitration, Part II, Kluwer Law International. The Hague 1999.

GAILLARD, E./BANIFATEMI, Y.:"IAI Series on International Arbitration No 5 Precedents", International Arbitration, 2008.

GARRO, A.: Comparison Between Provisions of the CISG Regarding Exemption of Liability for Damages (Art. 79) and the Counterpart Provisions of the $\begin{array}{llll}\text { UNIDROIT Principles } & \text { (Art. }\end{array}$ http://cisgw3.law.pace.edu/cisg/principles/uni79.htm.

GOODE, R.: Commercial LawPenguin Books, Ed. 3, London 2004.

GREENBERG, S. / KEE, C/ WEERAMANTRY, R.: International Commercial Arbitration: An Asia-Pacific Perspective, Cambridge, 2011.

HORN, N.: "Procedures of Contract Adaptation and Renegotiation in International Commerce", Adaptation and Renegotiation of Contracts in International Trade and Finance, Antwerp, Boston, London, Frankfurt 1985.

JEMIELNIAK, J.: Legal Interpretation in International Commercial Arbitration, Routledge, London, New York, 2016.

KILIÇOĞLU, A.: Borçlar Hukuku Genel Hükümler, Turhan Kitabevi, Ankara 2019. 
LANDO, O.: "Salient Features of the Principles of European Contract Law: A Comparison with the UCC”, Pace International. Law Review 2001, Vol. 13, No. 2, s. 339-369.

LEW, J./ MISTELIS, L./ KRÖLL, S.: Comparative International Commercial Arbitration, Kluwer Law International, The Hague 1994.

MANIRUZZAMAN, A.F.M.: “International Energy Contracts and Crossborder Pipeline Projects: Stabilization, Renegotiation and Economic Balancing in Changed Circumstances- Some Recent Trends", Oil, Gas \& Energy Law Intelligence 2006, Vol. 4, No. 4, s. 1-18.(International Energy Contract)

MANIRUZZAMAN, A. F. M.: "The Lex Mercatoria and International Contracts: A Challenge for International Commercial Arbitration”, American University International Law Review 1999, Vol.14, No. 3, s. 658-734.

MANIRUZZAMAN, A.F.M.: "State Contracts with Aliens: The Question of Unilateral Change by the State in Contemporary International Law", Journal of International Arbitration 1992, Vol. 9, No. 4, s. 141-172. (State Contracts with Aliens)

McARTHUR, J.B.: "The Take-or-Pay Crisis: Diagnosis, Treatment, and Cure for Immorality in the Marketplace”, New Mexico Law Review 1992, Vol. 22, No. 2, s. 354-458.

McKENDRICK, E.: Contract Law, Palgrave Law Masters, Ed.4, New York 2000.

MELIS, W.: "Force Majeure and Hardship Clauses in International Commercial Contracts in View of the Practice of the ICC Court of Arbitration", Journal of International Arbitration 1984, Vol. 1, No. 3, s. 213-221.

OĞUZMAN, K./ÖZ, T.: Borçlar Hukuku Genel Hükümler, C. 1, B. 17, Vedat Kitapçılık, İstanbul 2019

ÖZÇELIK, B. Ş.: Borçlunun Sorumlu Olmadığı Sebeplerle Borcun İfa Edilmemesi ve Mücbir Sebep Kayıtları, Yayınlanmamış Doktora ezi, Ankara Üniversitesi Sosyal Bilimler Enstitüsü, Ankara 2009.

ÖZEL, S.: Milletlerarası Ticari Tahkimde Kanunlar İhtilafı Meseleleri, Legal, İstanbul 2008.

Park, W.: "Gaps and Changed Circumstances in Energy Contracts: The Devil in the Detail”, Journal of World Energy Law \& Business 2015, Vol. 8, No. 2, s. 89100.

PAZARCI, H.: Uluslararası Hukuk Dersleri, 1. Kitap, B.14, Turhan Kitabevi, Ankara 2017.

PAZARCI, H.: Uluslarararası Hukuk, B. 18, Turhan Kitabevi, Ankara 2019. 
PETER, W.: Arbitration and Renegotiation of International Investment Agreements, Second and Enlarged Edition, Kluwer Law International.The Hague/Boston/London 1995.

POUDRET, J-F./ BESSON, S./ BERTI,S./ FONTI, A.: Comparative Law of International Arbitration, Ed.2, Sweet \& Maxwell Ltd, London 2007.

PUELINCKX, A.H.: Frustration, Hardship, Force Majeure; Imprevision; Wegfall der Geschäftsgrundlage; Unmöglichkeit, Changed Circumstances: A Comparative Study in English, French, German and Japanese Law, Journal of International Arbitration 1986, Vol. 3, No .2, s. 47-66.

QURASHI, Z.: Renegotiation of International Petroleum Agreements, Journal of International Arbitration 2005, Vol. 22, No. 4, s. 261-300.

RÖSLER, H. (Çev. AYDIN-ÜNIVER, T.): Alman ve Uluslararası Sözleşme Hukukunda Değişen ve Öngörülemeyen Koşullar, IÜHFM 2008, C. LXVI, No.1, s. 353-363.

SCHWENZER, I.: Force Majeure and Hardship in International Sales Contracts, Victoria University of Wellington Law Review 2008 , Vol. 39, No. 4, s. 709726.

SEROZAN, R.: İfa, İfa Engelleri, Haksız Zenginleşme (Kocayusufpaşaoğlu, Y./Hatemi, H. /Serozan, R./Arpac1, A: Boorçlar Hukuku Genel Bölüm, C.3, B.7, Filiz Kitabevi, İstanbul 2016.

SILBERMAN, L./FERRARI, F.: "Getting to the Law Applicable to the Merits in International Arbitration and Consequences of Getting It Wrong", Conflict of Laws in International Arbitration, (Eds. Ferrari, F./ Kröll, S.) European Law Publishers, 2011.

SORNARAJAH, M.: Supremacy of the Renegotiation Clause in International Contracts, Journal of International Arbitration 1998, Vol. 5, No. 2, s. 97-114.

STROHBACH, H.: Force Majeure and Clauses in International Commercial Contracts and Arbitration: The East-German Approach, Journal of International Arbitration 1984, Vol. 1, No. 1, s. 39-52.

ŞAHIN, H.: Mücbir Sebep Nedeniyle Borcun İfa Edilmemesi, Yetkin Yayınları, Ankara 2020.

ŞANLI, C.: Milletlerarası Tahkimde Esasa Uygulanacak Hukuk, Ankara 1986. 